\title{
Çok Kriterli Karar Verme Yöntemlerinden Ahp Ve Topsıs'in E-Kitap Okuyucu Seçiminde Uygulanması
}

\author{
Üstün ÖZEN \\ Kenan ORÇANLI*
}

\section{Özet}

Günümüzde bilgi teknolojilerinde meydana gelen hızlı değişim, özellikle yayıncılık sektöründe birçok yeniliklere neden olmuştur. Elektronik yayıncılık sektöründe meydana gelen bu yeniliklerden birisi de e-kitaptır. E-kitap, okuyuculara herhangi bir kitabın içeriğine elektronik formda erişim imkânı veren kitaplardır. Bu e-kitaplar notebook, netbook, masaüstü PC gibi elektronik cihazlarla okunabilmektedir. Ancak, komple bir e-kitabın varlığından söz edebilmek için standart olarak kullanılan bilgisayarların haricinde özel bir donanımın bulunması gerekir. Bu donanım, e-kitap okumak için özel olarak tasarlanmış "e-kitap okuyucu" adı verilen bir kitap okuma cihazıdır.

Yapılan çalışma da, e-kitap okuyucu seçimiyle ilgili bir karar süreci oluşturulmak istenmiştir. E-kitap okuyucu seçimi problemi çok kriterli karar verme problemi olarak düşünülebilir. Literatürde yer alan çok kriterli karar verme çözüm yaklaşımlarının e-kitap okuyucu seçimi problemine de uygulanması mümkündür. Oluşturulan karar sürecinde Analitik Hiyerarşi Prosesi $(A H P)$ ve TOPSIS (Technique for Order Preference by Similarity to Ideal Solution) yöntemleri kullanılmıştır..

\section{Anahtar Kelimeler: E-Kitap, Okuyucu, AHP, TOPSIS}

\section{The Implementation In Choosing E-Book Reader Of Ahp And Topsis That Are The Methods Of Multi-Criteria Decision Making}

\begin{abstract}
Today, the rapid changes in information technology has especially led to innovations in the publishing industry. One of these innovations in the publishing industry is the electronic book. The E-books are those that give the opportunity to access any books in electronic form on the contents of the book to readers. These e-books can be read with electronic devices like notebook, netbook, PC etc. But, the existence or presence of e-book is
\end{abstract}

* Prof. Dr., Atatürk Üniversitesi, İ̈BF, Yönetim Bilişim Sistemleri.

** Türk Silahlı Kuvvetleri 
required a special hardware. This equipment is the device that is called "ebook reader" and is specially designed for reading a book.

In this study, a decision process has been aimed about e-book reader selection. The problem of e-book reader selection can be considered as a problem of the multi-criteria decision making. In this respect, the solution approaches in the literatüre is available for the multi-criteria decisionmaking selection problem in the implementation of e-book reader. It is possible to carry out the solution approaches of the multi-criteria decision making in literature to the problems of e-book reader selection. In this decision process, the AHP and TOPSIS (Technique for Order Preference by Similarity to Ideal Solution) methods have been used.

Keywords: E-Book, Reader, AHP, TOPSIS

\section{Giriş}

Çağımızda okuma-yazma bilen, aritmetik bilgileri olan kişileri tanımlamakta kullanılan eğitimli insan tanımı değişmiştir. Bugün bilgi toplumunda eğitimli insan, kendisi ile ilgili gelişmeleri takip edebilen, bunları hayatında uygulayan, sorgulayan, gelişime açık, bilgi ve iletişim teknolojilerini aktif olarak kullanabilen bir kişi anlamına gelmektedir (Hayat Boyu Öğrenme Strateji Belgesi, 2009: 2).

Eğitimli insanın sahip olduğu belki en önemli özelliği, bilgi ve iletişim teknolojilerini aktif olarak kullanabilmesidir. Günümüzde bilgi teknolojilerinde çok hızlı değişim ve gelişim yaşanmaktadır. Bunun sonucu olarak bilgi ve iletişim teknolojilerinin kullanımı, toplumsal yaşamın her alanında ve bireyler arasında giderek yaygınlaşmış ve bu durum bireyin bilgiye ulaşmasını kolaylaştırmıştır. Ancak, bu gelişmeye rağmen okuma eylemi, bilginin edinilmesinde hâlâ en önemli ve en etkili araçtır (Özbay, 2007).

Bilişim teknolojilerindeki gelişim insanların günlük yaşantılarında ve okuma alışkanlıklarında değişim yaşanmasına sebep olmaktadır. Alışılagelmiş kitaplar ve okuma alışkanlıkları gün geçtikçe yerini elektronik ortamlarda hazırlanan kitaplara bırakmaktadır. $\mathrm{Bu}$ gelişmeler doğrultusunda kitap, gazete, dergi gibi birçok basılı materyal okurlarına elektronik ortamlardan ulaşmaktadır. Bu sayede gelişmiş bir veri tabanı oluşmaya başlamış, kullanıcı sayısı da bununla doğru orantılı olarak gün geçtikçe artış göstermiştir (Yıldırım vd. 2011: 2).

Bilişim teknolojilerinde meydana gelen bu gelişmelerin ürünlerinden birisi de e-kitaptır. Literatürde e-kitap hakkında çok farklı 
tanımlar yapılmış ve zaman zaman kavram karmaşası yaşanmıştır. E-kitabı en geniş anlamda 'basılı kitabın içeriğinin sayısal forma dönüştürülerek elektronik ortamda yayınlanmış, bu ortamda kullanılan çeşitli protokoller ve yazılımlar ile bunları kullanan bilgisayarlar veya bu konu ile ilgili özel olarak dizayn edilmiş okuyucular aracılığg ile izlenebilen metin, resim, film ve sesleri barındıran bir medya formatı' olarak tanımlamak mümkündür. Yani teknik olarak, diz üstü, masa üstü, cep bilgisayarları ve diğer e-kitap okuyucu cihazlar ile okunabilen ve basılı kitapların tıpkı kopyalarından oluşan elektronik dosyalar olarak tanımlanabilen e-kitap, bilgisayarlar ya da taşınabilir e-kitap okuyucuları ile okunmak için tasarlanmış, kâğıda basılmayan ama basılı kitapların bütün özelliklerini barındıran, ek olarak okuyucuya yeni kolaylıklar da sağlayan yeni bir kitap biçimidir.

E-kitap tanımdan da anlaşılacağı üzere donanım ve yazılım unsurlarından meydana gelmektedir. $\mathrm{Bu}$ açıdan değerlendirildiğinde e-kitaplar, özel olarak geliştirilmiş taşınabilir bir elektronik cihaz üzerindeki elektronik veriyi okumak amaciyla kullanılan bir yazılım-donanım kombinasyonunu çağrıştırmaktadır (Rukancı ve Anameriç, 2003, 148).

E-kitaplar masaüstü PC, notebook, netbook gibi birçok elektronik cihaz ile okunabilmektedir. Ancak bu elektronik cihazların haricinde sadece bu amaç için özel olarak hazırlanmış başka elektronik cihazlarda bulunmaktadır. E-kitap için özel olarak hazırlanmış ve diğer elektronik cihazlara karşı belirli üstünlükleri olan bu cihazlara e-kitap okuyucu adı verilmektedir. Çeşitli kaynaklardan alınan farklı yorumlar değerlendirildiğinde, e-kitap okuyucunun ne olduğu; diğer elektronik cihazlardan farkı; donanım mı yoksa yazılım mı veya bunların bileşimi mi olduğu konularında uzman çevrelerin ortak bir görüşe sahip olmadığı anlaşılmaktadır ve dolayısıyla literatürde bir kavram karmaşası yaşanmaktadır.

Dünyada, e-kitap okuyucularının sahip olması gereken temel niteliklerin belirlenmesine yönelik çalışmalar yapılmıştır (Kim vd. 2010). Ancak, ülkemizde bu konuda kapsamlı bir çalışma henüz yapılmamıştır (Önder, 2010). Bu durum düşünüldügünde, yapılan çalışmada, bir e-kitap okuyucunun hangi özelliklere sahip olması gerektiği ile ilgili kısa bir literatür taraması yapılmış ve bunun sonucunda e-kitap okuyucusu seçimi ile ilgili çok kriterli karar verme yöntemlerinden iki tanesi uygulanmaya çalışılmıştır. Birlikte uygulanan yöntemlerin aşamaları Tablo 1'de sunulmuştur. 
Tablo 1: AHP-TOPSIS Yöntemi Aşamaları

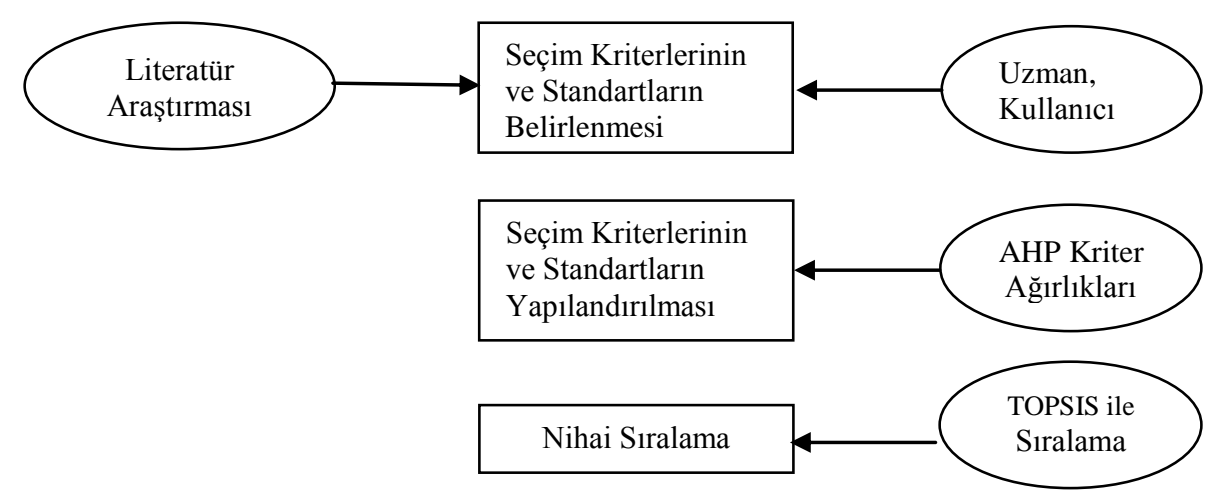

\section{Literatür Araştırması}

\section{E-Kitap Okuyucusu}

Kitap, her zaman insanın bilgilenme, öğrenme ve eğitim sürecindeki en temel iletişim aracı olmuştur. 1450'li yıllarda Johann Gutenberg'in matbaayı icat etmesiyle büyük bir gelişim gösteren kitap endüstrisi, iletişim ve bilgi teknolojilerine paralel olarak sürekli bir değişim içindedir.

Günümüze kadar ortaya konan tüm eğitim teknolojilerinin temelinde, bilginin sahip olduğu ve paylaşım hızına erişme amacı yatmaktadır (Barkan, 1994: 2). Bu amaca bir takım çağdaş eğitim taleplerinin eklenmesi ile eğitim teknolojilerinde yeni arayışlara zemin oluşturmuştur. $\mathrm{Bu}$ bağlamda, modern teknoloji ürünleri (bilgisayar ve ürünleri, e-kitap teknolojisi) eğitim hizmetine sunulmuştur. E-kitaplar bu arayışların son halkasını oluşturmaktadır (Anameriç ve Rukancı, 2003).

E-kitap, sayısal dağıtım amacıyla sayısal formata çevrilmiş referans kitabı, ders kitabı, ticari kitap gibi her türlü yayınlanmış materyal; teknolojinin olanakları ile düzenlenen, metin ve resmin yanı sıra ses ve hareketli görüntüleri de içerebilen, dijital okuma cihazlarılyla okunabilen materyaldir (Konya, 2004: 67).

Günümüzde dijital okuma cihazına e-kitap okuyucu denmektedir. E-kitap okuyucusunun sahip olması gereken özelliklerle ilgili literatürde çok sayıda ve çok farklı görüşler bulunmaktadır. E-kitap okuyucunun hangi özelliklere sahip olması halen fikir birliğine varılamamış bir konudur. Literatürdeki e-kitap okuyucularının sahip olması gereken özelliklerle ilgili olarak; 
- Yıldırım vd. (2011) tarafından 2000-2011 yılları arasında Web of Science and ERİC tabanlarında taranan e-kitap okuyucuların kullanımına yönelik deneyimlerin yer aldığı çalışmalar incelenmiştir. Elde edilen bulgulara göre e-kitap okuyucuların kapasite, taşınabilirlik ve çoklu ortam özelliklerinin kullanıcıların beğenisine hitap ettiği saptanmıştır. E-kitap okuyucuları için geliştirilen içeriklerin ortak bir standarda sahip olmamaları ve içerik paylaşımına izin vermemeleri önemli sınırlılıklar arasında sayılmıştır. Ayrıca, çalışmanın öneriler bölümünde, kullanıcıların e-kitap okuyucu tercihinde çoklu ortam desteği, kablosuz ağ erişimi, ekran boyutu ve çözünürlüğü, estetik görünüm, uzun batarya ömrü ve değiştirilebilir yazı tipi ve boyutu göz önüne alınması tavsiye edilmektedir.

- Bilişim teknolojileri uzmanı olan Yazıcı (2011) tarafından yapılan araştırmada, bir e-kitap okuyucusu almak için alıcının cihazın büyüklüğüne, dâhili disk boyutuna, ekran boyutuna, kablosuz bağlantı özelliğine dikkat etmesi gerektiğini ve satın almadan piyasada çok iyi araştırmanın yapılması gerektiği belirtilmektedir. Ayrıca, Mart 2012 tarihinde kendine ait web sitesinde Türkiye'de en çok tercih edilen e-kitap okuyucuların Kindle 3, Nook Simple Touch Reader, Nook Tablet, Kindle Fire, Kindle DX, Nook Color, Sony Reader Touch Edition, Sony Reader Daily Edition, Nook 1st Edition, Kobo Wireless eReader olduğunu ortaya koymuştur.

- $\mathrm{ABD}^{\prime}$ de 25 adet (dokümanda 10 adedi önerilmektedir.) e-kitap okuyucusu arasında yapılan karşılaştırmada, kriter olarak 9 adet kriter ele alınmıştır. Ele alınan kriterler sırasıyla ağırlık, klavye şekli(dokunmatik olup olmadı ‘̆g), batarya ömrü, ekran büyüklüğü, sayfa çevirme özelliği, destek dosyaları, ekranın okunabilirliği, çok yönlülük (versatility) ve navigasyon kriterleridir. Bu kriterlere göre yapılan karşılaştırma sonucunda Nook Simple Touch modeli en iyi ikinci model seçilmiştir. En iyi model Nisan 2012'de çıkan Nook Simple Touch e-kitap okuyucunun aydınlatmalı modeli seçilmiştir. Bizim tarafımızdan yapılan çalışmada ise Nook Simple Touch yine ikinci sırada yer almıştır. Bu sonuç, e-kitap okuyucu seçimiyle ilgili yapılan çalışmada ortaya konan karar modeli sonuçlarını desteklemektedir.(Consumer Reports, 2012: 30-31)

- Jung vd. (2011) tarafından e-kitap okuyucusunun kullanımını etkileyen faktörlerin belirlenmesine yönelik yapılan çalışmada, bağımsız değişkenler 5 kategoride ele alınmıştır. Çalışmanın sonucunda, e-kitap okuyucularının genç, yüksek gelirli ve yüksek eğitimli insanlar tarafından tercih edildiğini ve cinsiyet olarak herhangi bir farklılığın olmadığı ortaya konmuştur. Gazete, dergi okuma ile televizyon seyretme değişkenleriyle e- 
kitap okuyucusu kullanma arasında ilişki anlamsız bulunmuş, ancak internet kullanıcıları arasında pozitif bir ilişkiye rastlanmıştır.

- Abdullah ve Gibb (2008) tarafından yapılan çalışmada, okuyucuların basılı bir kitabın elektronik haline tercih ettikleri yönünde birçok araştırma olduğu belirtilmektedir. Ancak, e-kitapların arama yapma, not alma, yazı şeklini değiştirme gibi kolaylaştırıcı seçenekler sunulduğu takdirde daha cazip hale geleceği ifade edilmektedir.

- Mahajan and Chakravarty (2007) ve Jung and Lim (2009) çalışmalarında, e-kitapların öne çıkan yararlı ve olumsuz taraflarını incelemişlerdir. Çalışmalarında, tasarlanma aşamasında dünyada herhangi bir standartın bulunmadığını ve önemli bir eksiklik olduğunu belirtilirken, e-kitapların kolay güncelenebilir olması, çoklu ortama uyum sağlanabilir olması, taşınabilir olması ve internet ortamında kullanılırken çeşitli güvenlik sorunlarının yaşanmaması için kuvvetli yazılımların olması gerektiğini vurgulamaktadırlar.

- Wilson ve Landoni (2008) tarafından yapılan bir araştırmada, ekitap okuma cihazlarının satın alınmasında dikkat edilecek özelliklerle ilgili genellenebilir bir takım özelliklere ulaşılmıştır. Bir e-kitap okuma cihazı seçilirken cihazın e-ink teknolojiye sahip olmasına, ara yüzün kolay okunması için ekranın oynar olmasına, güneş ışığında okunabilir olmasına, cihaz ekranının boyutlarına (ekran boyutu e-kitabın kullanım amacına göre seçilmesi fayda sağlayacaktır. Çünkü eğitimde görselliği önemli olmasından dolayı daha çok büyük ekranlı seçilmesi uygun olacaktır.), desteklenen dosya formatına (EPUB mı yoksa AZW mi), ağ bağlantısı çeşidine (Wi-Fi veya $3 G$ ), bataryanın uzun süre dayanmasına, hafıza ve ek özelliklerine, ağırlığına, ekran ölçülerine dikkat edilmesi gerektiği belirtmektedir.

- Bilişim uzmanı olan Ganapati (2010) tarafından yapılan araştırmada, e-kitap okuyucusu almak isteyen kişilerin cihazda aramaları gereken kriterler sıralanmıştır. Bu kriterler sırasıyla, cihazın kolay taşınabilir olması, bataryanın dayanma süresinin uzun olması, gözleri yormayan ekran özelliğinin olması, güneş ışığında parlamaması, donanım ve yazılım özelliklerinin en son özelliklerde olması, USB çıkışının olması, e-kitapların aygıta yüklenecek servisinin çok olmasıdır.

- The Business School of the University of Manchester de, 2010 yılının yaz ayında MBA öğrencileri arasında yapılan araştırmada, e-kitap okuyucuların eğitim ve öğretimde kullanılmasının cihazın taşınabilirlik ve boyutlarının küçük olmasından dolayı oldukça yararlı olduğunu belirtmişlerdir. Ancak bir e-kitap okuyucusunda sadece kitap değil gazete, dergi gibi diğer yayınlarında bulunması gelecekte daha fazla kullanıcı 
tarafından tercih edileceği vurgusu yapılmıştır. Ayrıca, doküman yükleme işlemlerinin daha hızlı olması, internet bağlantısının bulunması, dokümanlar arasında geçişin olabilmesi, cihazın çok yönlü olarak kullanılabilmesi gibi kriterlerinde bulunması cihazın kullanılabilirliğini artırdığını belirtmektedirler. (Broadhurst ve Watson, 2012),

- Chu (2003) tarafından yapılan araştırmada, yeni bir kitap yüklenmek istendiğinde yavaş yükleme sorunları, web tarayıcısı sorunları ve e-kitap içinde herhangi bir bilgiye ulaşmak istendiğinde dolaşım konusunda istenilen verimin sağlanamaması gibi teknik olumsuzlukların, ekitapların okuyucu tarafından kabul edilirliğini azaltan etkenler olduğunu ortaya koymaktadır. Tabi ki bu durum yazılım ve donanımdan kaynaklanan sorunlardir.

- McPall (2005) tarafından yapılan çalışmada, halen basılı kitapların sınıf içinde öğretmen ve öğrenciler tarafından öncelikli kaynak olduğunu belirtilirken, ayrıca, çoklu ortam içeren e-kitaplarında gelecekte yararlı kaynak olacağı vurgulanmaktadır.

- Lam vd. (2009) tarafından yapılan çalışmada, e-kitap okuyucularıyla ilgili olarak teknik yardım boyutunun nasıl olması gerektiği konusu ele alınmıştır. Bir e-kitap okuyucunun satın alınmada dikkat edilecek en önemli kriterlerinden ikisinin o cihaza ait teknik servislerin yaygın olması ve karşılaşılan teknik bir arızanın kısa sürede giderilip giderilmediği olduğu vurgulanmaktadır. Ayrıca, e-kitap okuyucu kullanıcısı karşılaştığ ${ }_{1}$ teknik sorunların üreten firma ekiplerince süratle giderildiğini fark ettiğinde e-kitap okuyucuya daha fazla bağlanacağını ve okuma eylemini daha fazla seveceği belirtilmektedir.

- Soules (2008) yaptı̆̆ çalışmada, video, resim ve ses öğeleri ile zenginleştirilmiş etkileşimli ortamlarının günümüzde yaygın olmadığını belirtmekte beraber gelecekte sayılan özelliklerin gelişeceğini umduğu ve eğitim için olduğu gerekli olduğunu ifade etmektedir.

- Marlett (2010) tarafından İngiltere'de The Cranfield University ve The Open University'de e-kitap okuyucularının kullanımına etki eden faktörlerin belirlenmesi amacıyla hiç e-kitap okuyucu kullanmayan 12 öğrenci arasında üç aylık bir sürede bir araştırma yapmıştır. Araştırmaların bulgularına göre ideal bir kitap okuyucusunda, A4 veya A5 büyüklüğünde olması, fiyatının ucuz olması, internet girişinin olması, üzerinde yapılacak işlemlerin kolay bir şekilde yapılması, dokunmatik ekran ve başka bilgisayarlarla bağlanabilme özelliğine sahip olması, kitap içinde aranılan bir kelimenin kolaylıkla bulunabilmesi için arama motorunun bulunması, 
hafif ve taşınabilir olması gibi özelliklerin bulunması gerektiği sonucuna ulaşmıştır.

\section{TOPSIS ve AHP Yöntemleri}

İç ve Yurdakul (2001) tarafından yapılan çalışma da, günümüzdeki rekabet koşullarının imalat firmalarını daha kaliteli, daha esnek ve daha hızlı üretime zorladığını, işleme merkezlerinin sürekli değişen pazar koşullarına uyum sağlayabilmek ve artan ürün çeşitliliğini karşılamak zorunda kalan imalat sistemlerinin önemli bir parçası olduğu ve model ile çeşitlilik açısından oldukça geniş bir yelpazeye sahip olan işleme merkezleri arasından seçim yapabilmek oldukça karmaşık fakat önemli bir karar olduğu belirtilmektedir. Bu kapsamda, işleme merkezlerinin seçimiyle ilgili AHP ve TOPSIS yöntemlerinin bulanık mantıkla uygulandığı bir karar destek sistemi geliştirilmiştir.

Yurdakul ve İç (2003) tarafından yapılan başka bir çalışmada ise, Türkiye'de otomotiv sanayinde faaliyet gösteren ve İstanbul Menkul Kıymetler Borsası'nda (IMKB) işlem görmekte olan beş büyük ölçekli otomotiv firmasının bilançoları kullanılarak firmaların derecelendirilmesinde TOPSIS Yöntemi kullanılmıştır.

Küçük ve Ecer (2007) tarafından yapılan çalışmada, bir mağazalar zincirine mal ve hizmet sunan tedarikçileri değerlendirmeye yönelik bir model ortaya konmuş ve bu modelde bulanık TOPSIS Yöntemi kullanılmıştır.

Başkaya ve Öztürk (2011) tarafından yapılan çalışmada, üst, orta ve alt konsept seviyelerinde 17 adet satış mağazası bulunan bir işletmenin satış elemanı seçim süreci incelenmiştir. İnceleme sürecinde bulanık TOPSIS yöntemi uygulanmış ve bulanık TOPSIS algoritmasının daha hassas karar vermeyi desteklemesi açısından yamuk bulanık sayılar kullanılmıştır. Bulanık TOPSIS algoritmasının satış elemanı seçiminde, bulanık çok kriterli bir grup karar verme tekniği olarak etkin bir şekilde uygulanabileceği gösterilmiştir.

Çınar (2010) tarafından yapılan çalışmada, bir kuruluş yeri seçimi problemi ele alınmış ve bankacılık sektöründe faaliyet gösteren bir bankanın, hiç şubesinin bulunmadığı Güneydoğu Anadolu Bölgesi'nde beş aday şehir arasından doğru tercih yapabilmesine yönelik bir karar modeli ortaya konmuştur. Geliştirilen karar modelinde, çok ölçütlü karar verme yöntemlerinden, değerlendirme süreçlerinin bulanıklığından dolayı, aralıklı karar vermeyi olanaklı kılan bulanık TOPSIS yöntemi uygulanmıştır. 
Şahin ve Akyer (2011) tarafından yapılan çalışmada, devletin üstlendiği görevler nedeniyle kamu kurumlarının belirli harcamalar yapmaları gerektiği ve harcamaların en önemli kalemlerinden birisi de araç alımları olduğu belirtilmektedir. Bu kapsamda çalışmada, 4x4 arama kurtarma aracı seçiminde AHP ve TOPSIS yöntemlerinin kullanımı ele alınmıştır.

\section{AHP Yöntemi ve Matematiksel Bakış}

AHP, Thomas L.Saaty tarafından geliştirilen çok kriterli karar verme yöntemlerinden biridir. İnsan doğasında var olan ikili karşılaştırmalar ile seçeneklerin ve kriterlerin birbirine göre ne kadar önemli, tercih edilebilir veya baskın olduğunu değerlendirir. (Özgörmüş, Mutlu ve Güner, 2005: 12). $\mathrm{AHP}$, hem objektif, hem de sübjektif değerlendirme kriterlerini dikkate alabilen ve yaygın olarak kullanılan çok kriterli karar verme tekniğidir. (Karaçolak ve Ünal, 2012: 3)

1970'li yıllarda Saaty tarafından ABD Savunma Bakanlığında silahsızlanma ve Orta Doğu sorunu için ulaştırma sisteminin geliştirilmesi gibi karmaşık problemler üzerinde çalışılmıştır. Matematik ve yöneylem araştırması alanına birçok teorik katkıda bulunan Saaty, giderek karmaşıklaşan modelleme yaklaşımlarının, karar problemlerinin çözümünde beklenen etkiyi yapmadığını görmüş ve karmaşık karar problemlerinin çözümünde kullanılmak üzere kolay anlaşılan ve uygulanan bir teknik geliştirme uğraşına girmiştir. Çalışmaların sonucunda AHP adı ile anılan tekniği geliştirmiştir.

Aşağıda, AHP'nin teorik çerçevesi sunulmuştur.

Adım 1: Alternatiflerin setini gösteren $\mathrm{A}^{\prime} \mathrm{da} i$ ve $j$ alternatifleri dikkate alındığında karar vericinin kriterler seti $C^{\prime}$ nin bir elemanı olan $c$ kriterine göre bu iki alternatifin kıyaslaması aij ile gösterildiğinde $a_{j i}=1 / a_{i j}{ }^{\prime}$ dir.

Adım 2: Karar verici alternatifleri arasında kriterlerine göre kıyaslama yaparken hiçbir zaman sonsuz kat daha iyi/kötü sonucuna ulaşamaz.

Adım 3: Bir karar problemi hiyerarşik olarak formüle edilebilir.

Adım 4: Karar problemini etkileyen tüm kriter ve alternatifler hiyerarşik yapı içinde yer alır. Diğer bir değişle karar vericinin problemle ilgili olduğunu düşündüğü tüm kriter ve alternatifler yapı içinde değerlendirilmeli ve sezgiler doğrultusunda ağırlıklandırılmalıdır.

Yukarıda verilen adımlardan 3 ve 4 numaralı olanlar karar probleminin formülasyonu ve çözümünün hiyerarşik bir yapı yardımıyla olacağını 1 ve 2 numaralı adımlar ise ikili kıyaslamalar sürecinde hangi çerçevede mantık yürütüleceğini göstermektedir. 
Geliştirilmiş olan tüm karar alma yöntemleri karar vericinin tercihlerinde tamamen tutarlı olduğunu ve hata yapmadığını varsaymaktadır. AHP, karar vericinin yargılarında tamamen tutarlı olması gerekmediği varsayımıyla diğer karar alma metodolojilerinden ayrilmaktadir.

AHP metodolojisi çerçevesinde ikili kıyaslamalar matrisinden ağırlıkların elde edilmesi için çeşitli yöntemler bulunmaktadır. Bu yöntemler arasında en yaygın olarak kullanılan Saaty'nin geliştirdiği Öz Vektör Metodu'dur.

AHP'de incelenmesi gereken hususların başında $A=(i, j)$ ikili kıyaslamalar matrisi verildiğinde bu matristen hareketle kriterler için ağırlıkların ve alternatifler için tercih derecelerinin bulunması gerekmektedir. AHP ile ilgili yapı verilirken açıklandığı üzere $A$ matrisi pozitif ve ters değerlerden oluşmaktadır.

$$
A_{i j}=\left[\begin{array}{cccc}
a_{11} & a_{12} & \ldots & a_{1 n} \\
a_{21} & a_{22} & \ldots & a_{2 n} \\
\cdot & & & \cdot \\
\cdot & & & \cdot \\
\cdot & & & \cdot \\
a_{m 1} & a_{m 2} & \ldots & a_{m n}
\end{array}\right]
$$

A matrisi yukarıdaki şekilde tanımlandığında ters değerler nedeniyle $a_{i j}=1 / a_{i j} \quad i, j=1,2, \ldots \ldots, n$ olur. Şimdi bu matris üzerinden $w=\left(w_{1}, w_{2}, \ldots . w_{n}\right)$ ağırlıkları bulunmaya çalışılır. Oransal ölçekte çalışılması nedeniyle ağırlıkların mutlak değerleri yerine göreli değerleri anlam kazanmaktadır. Bu nedenle, ağırlık değerleri toplamı basit ağırlıklandırma da olduğu gibi 1 olacak şekilde ölçeklendirme yapılacaktır.

Eğer karar vericilerin değerlendirmeleri tamamen tutarlı ise $a_{i k^{*}} a_{k j}=a_{i j}$ $i, j, k=1,2, \ldots, n$ olmalıdır. O zaman $A$ matrisinde hatadan bahsedilmez ve $a_{i j}=w_{i} / w_{j} \quad$ olarak yazılabilir. Bu sonuç $a_{i k}{ }^{*} a_{k j}=\left(w_{i}{ }^{*} w_{k}\right) /\left(w_{k}{ }^{*} w_{j}\right)=w_{i} / w_{k}=a_{i j}$ eşitliklerinden görülebilir. $A$ matrisinin herhangi bir $\mathrm{j}$ sütunu normalize edilerek nihai ağırlıklar elde edilebilir: $w_{j}=a_{i j} / \sum a_{k j} i=1,2, \ldots . . n$

Daha önce açılandığı üzere, genellikle hata yapılması veya tutarlı olunmaması sebebiyle seçilen sütuna bağlı olarak ağırlıkların aldığı değerler değişmektedir. Daha önce belirtildiği üzere hata altında ağırlık değerlerinin bulunmasına ilişkin esas olarak iki yaklaşım bulunmaktadır. Bunlar En Küçük Kareler Yöntemi ve Özvektör Metodu'dur.

En Küçük Kareler Yöntemi $\Sigma \sum\left(\ln a_{i j}-\ln w_{i}+\ln w_{j}\right)^{2}$ ifadesini minimize eden w setini ağırlık vektörü olarak almaktadır. 
Özvektör Metodu ise $w$ ağırlıklarını A matrisinin Perron Vektörü olarak hesaplar.

$A_{w}=\lambda_{\max } w, w_{i}=\sum a_{i j} w_{j} / \lambda_{\max } i=1,2, \ldots . . n$

Özvektör yaklaşımı değerlendirmedeki tutarsızlık derecesinin tespit edilmesi gibi çeşitli avantajları bünyesinde içerdiği için yaygın olarak kullanılmaktadır. Saaty tarafından gösterildiği üzere pozitif ve ters değerli matrisler için $\lambda_{\max }>=n$ olur. $\lambda_{\max }=n$ şartı ise sadece ve sadece A matrisi tutarlı olduğu zaman geçerlidir. Bundan dolayı $\lambda_{\max }-n$ tutarsızlık bir göstergesi olarak kullanılabilmektedir. Saaty'nin normalize ederek tanımladığı şekliyle "tutarsizlık endeksi", $C I=\left(\lambda_{\max }-n\right) /(n-1)$ 'dir. Rassal olarak üretilen $n x n$ matrislerin hesaplanan $C I$ değerlerinin ortalaması rassal endeks (RI) olarak tanımlanmıştır. Tutarlılık oranı tutarsızlık endeks değerinin rassal endeks değerine oranı olarak tanımlanmaktadır. $C R=C I / R I^{\prime} d \imath$. Daha önce ifade edildiği üzere $C R<=0,1$ değeri kabul edilebilir olarak değerlendirilirken, $0,1^{\prime}$ den büyük değerler için karar vericinin değerlendirmelerindeki tutarsızlıkları azaltmak için yeniden değerlendirme yapması uygun bulunmaktadır. (Aktaş, 2004)

\section{TOPSIS Yöntemi ve Matematiksel Bakış}

Hwang ve Yoon (1981) tarafından geliştirilen TOPSIS (Technique for Order Preference by Similarity to Ideal Solution) yöntemi, sayılarla ifade edilebilen alternatifleri siraya koymada en etkin ve kolay kullanılabilen yöntemlerden biridir. TOPSIS Yöntemi çok kriterli problemlerin çözümünde alanındaki en etkili ve en kolay yöntem olarak bilinmektedir. TOPSIS Yöntemi kullanılarak alternatiflerin belirlenen kriterler temelinde karşılaştırılması neticesinde net öncelikleri tespit etmek mümkündür. Yöntemin temelinde, pozitif-ideal çözüme en kısa mesafe ve negatif-ideal çözüme en uzak mesafedeki alternatifi seçmeye dayanmaktadır (Shyjith, Ilangkumaran ve Kumanan, 2008: 376). TOPSIS Yönteminin adımları aşağıda sıralanmıştır.

\section{Adım 1: Amaçların belirlenmesi ve değerlendirme kriterlerinin} tanimlanmasi.

\section{Adım 2: Karar Matrisinin (A) Oluşturulması.}

Karar matrisinin satırlarında üstünlükleri sıralanmak istenen karar noktaları, sütunlarında ise karar vermede kullanılacak değerlendirme faktörleri yer alır. A matrisi karar verici tarafından oluşturulan başlangıç matrisidir. Karar matrisi aşağıdaki gibi gösterilir: 


$$
A_{i j}=\left[\begin{array}{cccc}
a_{11} & a_{12} & \ldots & a_{1 n} \\
a_{21} & a_{22} & \ldots & a_{2 n} \\
\cdot & & & \cdot \\
\cdot & & & \cdot \\
\cdot & & & \cdot \\
a_{m 1} & a_{m 2} & \ldots & a_{m n}
\end{array}\right]
$$

$A_{i j}$ matrisinde m karar noktası sayısını, n değerlendirme faktörü sayısını verir.

\section{Adım 3: Standart Karar Matrisinin (R) Oluşturulması.}

Standart Karar Matrisi, Karar matrisi ( $A$ ) oluşturulduktan sonra (5.1) nolu formül kullanılarak normalleştirilmiş karar matrisi $(R)$ elde edilir (Mahmoodzadeh vd., 2007: 138).

$$
r_{i j}=\frac{a_{i j}}{\sqrt{\sum_{k=1}^{m} a_{k j}^{2}}}
$$

R matrisi aşağıdaki gibi elde edilir:

$$
R_{i j}=\left[\begin{array}{cccc}
r_{11} & r_{12} & \ldots & r_{1 n} \\
r_{21} & r_{22} & \ldots & r_{2 n} \\
\cdot & & & \cdot \\
\cdot & & & \cdot \\
\cdot & & & \cdot \\
r_{m 1} & r_{m 2} & \ldots & r_{m n}
\end{array}\right]
$$

Adım 4: Ă̆ırlıklı Standart Karar Matrisinin (V) Oluşturulması.

Öncelikle amaca göre değerlendirme kriterlerine ilişkin göreli ağırlık değerleri $\left(w_{i}\right)$ belirlenir $\left(\sum_{i=1}^{n} w_{i}=1\right)$. Daha sonra $\mathrm{R}$ matrisinin her bir sütunundaki elemanlar ilgili $w_{i}$ değeri ile çarpılarak V matrisi oluşturulur. Ağırlıklı normalleştirilmiş karar matrisi $V_{i j}=\left(\omega_{i j} X R_{i j}\right)$ gösterilir (Rao, 2008: 444).V matrisi aşağıda gösterilmiştir:

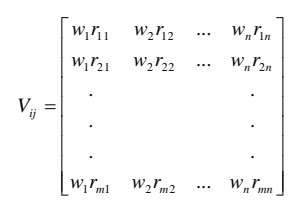




\section{Adım 5: Pozitif İdeal $\left(A^{*}\right)$ ve Negatif İdeal $\left(A^{-}\right)$Çözümlerin Oluşturulması.}

TOPSIS yöntemi, her bir değerlendirme faktörünün monoton artan veya azalan bir eğilime sahip olduğunu varsaymaktadır. İdeal çözüm ağırlıklı normalleştirilmiş karar matrisinin en iyi performans değerlerinden oluşurken, negatif ideal çözüm en kötü değerlerinden oluşur.

İdeal çözüm setinin oluşturulabilmesi için $\mathrm{V}$ matrisindeki ağırlıklandırılmış değerlendirme faktörlerinin yani sütun değerlerinin en büyükleri seçilir. İdeal çözüm setinin bulunması aşağıdaki formülde gösterilmiştir.

$$
A^{*}=\left\{\left(\max _{i} v_{i j} \mid j \in J\right),\left(\min _{i} v_{i j} \mid j \in J^{\prime}\right\}\right.
$$

(5.2) formülünden hesaplanacak set $A^{*}=\left\{v_{1}^{*}, v_{2}^{*}, \ldots, v_{n}^{*}\right\}$ şeklinde gösterilebilir.

Negatif ideal çözüm seti ise, V matrisindeki ağırlıklandırılmış değerlendirme faktörlerinin yani sütun değerlerinin en küçükleri seçilerek oluşturulur. Negatif ideal çözüm setinin bulunması aşağıdaki formülde gösterilmiştir.

$$
A^{-}=\left\{\left(\min _{i} v_{i j} \mid j \in J\right),\left(\max _{i} v_{i j} \mid j \in J^{\prime}\right\}\right.
$$

(5.3) formülünden hesaplanacak set $A^{-}=\left\{v_{1}^{-}, v_{2}^{-}, \ldots, v_{n}^{-}\right\}$şeklinde gösterilebilir.

Her iki formülde de $J$ fayda (maksimizasyon), $J^{\prime}$ ise kayıp (minimizasyon) değerini göstermektedir. Gerek ideal gerekse negatif ideal çözüm seti, değerlendirme faktörü sayısı yani m elemandan oluşmaktadır. (Yurdakul ve İç, 2001: 4613).

\section{Adım 6: Ayırım Ölçülerinin Hesaplanması.}

TOPSIS yönteminde her bir karar noktasına ilişkin değerlendirme faktör değerinin İdeal ve negatif ideal çözüm setinden sapmalarının bulunabilmesi için Euclidian Uzaklık Yaklaşımından yararlanılmaktadır. Buradan elde edilen karar noktalarına ilişkin sapma değerleri ise İdeal Ayırım $\left(S_{i}^{*}\right)$ ve Negatif İdeal Ayırım $\left(S_{i}^{-}\right)$Ölçüsü olarak adlandırılmaktadır. J alternatifin ideal çözümden uzaklığı İdeal ayırım $\left(S_{i}^{*}\right)$ ölçüsünün hesaplanması (5.4) formülünde, negatif ideal çözümden uzaklığı 
negatif ideal ayırım $\left(S_{i}^{-}\right)$ölçüsünün hesaplanması ise (5.5) formülünde gösterilmiştir.

$$
\begin{aligned}
& S_{i}^{*}=\sqrt{\sum_{j=1}^{n}\left(v_{i j}-v_{j}^{*}\right)^{2}} \\
& S_{i}^{-}=\sqrt{\sum_{j=1}^{n}\left(v_{i j}-v_{j}^{-}\right)^{2}}
\end{aligned}
$$

Burada hesaplanacak $S_{i}^{*}$ ve $S_{i}^{-}$sayısı doğal olarak karar noktası sayısı kadar olacaktır.

\section{Adım 7: İdeal Çözüme Göreli Yakınlığın Hesaplanması.}

Her bir karar noktasının ideal çözüme göreli yakınlığının $\left(C_{i}^{*}\right)$ hesaplanmasında ideal ve negatif ideal ayırım ölçülerinden yararlanılır. Burada kullanılan ölçüt, negatif ideal ayırım ölçüsünün toplam ayırım ölçüsü içindeki payıdır. İdeal çözüme göreli yakınlık değerinin hesaplanması aşağıdaki formülde gösterilmiştir.

$$
C_{i}^{*}=\frac{S_{i}^{-}}{S_{i}^{-}+S_{i}^{*}}
$$

Burada $C_{i}^{*}$ değeri $0 \leq C_{i}^{*} \leq 1$ aralığında değer alır ve $C_{i}^{*}=1$ ilgili karar noktasının ideal çözüme, $C_{i}^{*}=0$ ilgili karar noktasının negatif ideal çözüme mutlak yakınlığını gösterir.

Adım 8: Alternatifler ideal çözüme göreli yakınlık $C_{i}^{*}$ değerine göre siralanmasi.

\section{Uygulama}

\section{Uygulamanın Amacı}

Uygulamanın amacı, çok kriterli bir karar nesnesi olan e-kitap okuyucunun seçimde AHP ile birlikte TOPSIS yönteminin kullanımını oluşturmak ve ayrıca yöntemin gerçek hayat problemlerinde kullanılabilir olmasını gösterebilmektir. Bu yöntemin en önemli avantajı, karara pozitif etki eden faktörlerin yanında, karara negatif etki eden faktörlerin de kullanılabiliyor olmasıdır. 


\section{Uygulamanın Kapsamı}

Son yıllarda bilgi teknolojilerinde yaşanan hızlı değişim özellikle yayıncılık sektöründe yeniliklere neden olmuştur. Elektronik yayın türlerinden biri olan elektronik kitapların kullanımı da tüm dünyada ve ülkemizde büyük bir hızla gelişmektedir. Başta A.B.D. ve İngiltere'de olmak üzere gelişen e-kitap teknolojisi, e-kitap okuyucuların üretimindeki artış, bu pazarda yaşanan fark edilir rekabet nedeniyle daha popüler olmaya başlamıştır. İşte bu gelişmeler içinde en uygun e-kitap okuyucusunun nasıl seçilmesi gerektiği tüketiciler açısından önem arz etmektedir.

$\mathrm{Bu}$ kapsamda yapılan uygulama da, e-kitap okuyucuların sıralanması için gerekli kriterlerin tespiti için internetten yerli ve yabancı sitelerden ile bilimsel çalışmalardan yararlanılmıştır. Uygulaması yapılacak olan e-kitap okuyucuların seçiminde kullanılacak olan sayısal verilerin tespiti ise, internet ve uzman görüşleri kullanılmıştır. Seçim esnasında karşılaştırılacak olan e-kitap okuyucuların ilgili firmaların en son modelleri ve özellik itibarıyla birbirine en yakın olanlar seçilmiştir. Başlangıçta, bir e-kitap okuyucuların piyasada mevcut olan bütün teknik özellikleri alınmıştır. Daha sonra kriterler belirlendikten sonra kriterlere uygun olarak bu teknik özelliklerden bazıları kendi içinde gruplandırılmış, bazıları da elenme yoluna gidilmiştir. TOPSIS metodunda sıralama için gerekli olan bütün kriterlere ait veriler sayısal olarak ifade edilmeye çalışılmıştır.

Sıralama için gerekli olan ağırlıklandırma için uzman görüşü olarak donanımın değerlendirilmesi için 3 bilgisayar mühendisinin, yazılım ve çoklu ortamla ilgili özelliklerin değerlendirilmesi için 3 bilgisayar operatörünün, teknik destekle ilgili olarak bu işin pazarlama boyutunda görev yapan ve müşterilerin yaşadığı sorunların çözümü için uğraşan aynı anda aygitların durumundan teknik olarak anlayan 2 teknik personelin ve 1 kullanıcı olarak eğitim uzmanından yardım alınmıştır. Değerlendirme esnasında kendi ilgi alanlarıyla ilgili anket düzenlenmiştir. Daha sonra aynı kişiler kriterlerin Tablo 2'de bulunan ölçeğe göre ikili karşılaştırmalar yaparak üstünlüklerin oluşturulması istenmiştir.

Tablo 2: İkili Karşılaştırma Ölçeği

\begin{tabular}{|c|c|c|}
\hline $\begin{array}{c}\text { Önem } \\
\text { Derecesi }\end{array}$ & Tanımı & \multicolumn{1}{|c|}{ Açılaması } \\
\hline 1 & $\begin{array}{c}\text { Eşit derecede } \\
\text { önemli }\end{array}$ & $\begin{array}{l}\text { Her iki faaliyet amaca eşit katkıda } \\
\text { bulunur. }\end{array}$ \\
\hline
\end{tabular}




\begin{tabular}{|c|c|l|}
\hline $\mathbf{3}$ & $\begin{array}{c}\text { Orta derecede } \\
\text { önemli }\end{array}$ & $\begin{array}{l}\text { Tecrübe ve değerlendirmeler } \\
\text { sonucunda bir faaliyet diğerine göre } \\
\text { biraz daha fazla tercih edilir. }\end{array}$ \\
\hline $\mathbf{5}$ & $\begin{array}{c}\text { Güçlü derecede } \\
\text { önemli }\end{array}$ & $\begin{array}{l}\text { Tecrübe ve değerlendirmeler } \\
\text { sonucunda bir faaliyet diğerine göre } \\
\text { çok daha fazla tercih edilir. }\end{array}$ \\
\hline $\mathbf{7}$ & $\begin{array}{c}\text { Çok güçlü derecede } \\
\text { önemli }\end{array}$ & $\begin{array}{l}\text { Bir faaliyet diğerine göre çok güçlü } \\
\text { şekilde tercih edilir. Uygulamada } \\
\text { üstünlüğü ispatlanmıştır. }\end{array}$ \\
\hline $\mathbf{9}$ & $\begin{array}{c}\text { Son derece önemli } \\
\text { Bir faaliyet diğerine göre mümkün olan } \\
\text { en yüksek derecede tercih edilir. }\end{array}$ \\
\hline $\mathbf{2 , 6 , 8}$ & $\begin{array}{c}\text { Yukarıdaki değerler } \\
\text { arasındaki ara } \\
\text { değerler }\end{array}$ & $\begin{array}{l}\text { Bir değerlendirmeyi yapmakta sözler } \\
\text { yetersiz kalıorsa, saysal değerlerin } \\
\text { ortasındaki bir değer verilir }\end{array}$ \\
\hline
\end{tabular}

Çalışmada, "http://ebook-reader-review.toptenreviews.com" internet sitesinde 2012 yılı itibarıyla en çok tercih edilen ve üreticilerin ürettiği en son teknolojik e-kitap okuyucuların teknik detayları verilmiştir. Ancak, bu karşılaştırılma hazırlandıktan sonra Sony ve Nook firmaları karanlıkta okunması için aydınlatma sistemine sahip Sony Reader PRS700BC ve Nook Simple Touch modellerini 2012 yılının Nisan aylarında piyasaya sürmüşlerdir. Ancak diğer e-kitap okuyucularda bu özellik olmadığından özellikleri itibarıyla birbirine yakın 10 e-kitap okuyucu seçilmiştir. Başlangıçta elde edilen ve yayınlanan e-kitap okuyucuların bütün özellikleri alınmıştır. Ancak sayısal olarak karşılaştırma yapmak için bu özellikleri literatür araştırmasında elde edilen ve bu çalışma da kullanılacak kriterlerle karşılaştırılarak hem gruplandırılmış hem de gerekli düzenlemeler yapılmıştır. Burada başlangıçta en önemli nokta kriterlerin belirlenmesi ve bu kriterler uygun olacak verileri seçmektir. Çünkü karşılaştırma başlangıçtan sona değin bu kriterler ve bu kriterlerin karşılığ olan sayısal veriler üzerinden yapılmaktadır. Bu kapsamda seçilen on model Kindle 3, Nook Simple Touch Reader, Nook Tablet, Kindle Fire, Kindle DX, Nook Color, Sony Reader Touch Edition, Sony Reader Daily Edition, Nook 1st Edition, Kobo Wireless eReader'dır. Bu on modele ait teknik detaylar ve kriterlere uyarlanışı Uygulama Verileri başlığı altında verilmiştir.

E-kitap okuyucuların karşılaştırılması için literatür taraması sonucunda 17 adet kriter belirlenmiştir. Bunlar;

K1 Yedek parça, bakım ve arıza durumu

K2 Yazılım, donanım ve karşılaşılan teknik sorunların çözümü 
K3 Batarya Ömrü

K4 Şarj Edilme Süresi

K5 Ağ Bağlantı Çeşiti (Wi-Fi veya 3G)

K6 Estetik görünüm

K7 Ekran Cinsi

K8 Ekran Çözünürlüğü

K9 Doküman Formatları

K10 Ses Format1

K11 Görüntü formatları

K12 Klavye

K13 Ekran Boyutu

K14 Harici Hafıza

K15 Dahili Hafıza

K16 Ağırlık

K17 Fiyat'tır.

Kriterlerden K1, K2, K6, K9, K10, K11 kodlu kriterler incelendiğinde nitel değişkenler olduğunu görmekteyiz. Bu kriterler sayısal değere çevrilmeden herhangi bir işleme tabi tutulamamaktadır. Bu nedenle bu kriterleri değerlendirmeye alabilmek amacıyla uzman görüşlerine başvurulmuştur. Kriterler uzmanlık düzeyine göre değerlendirmeleri istenmiştir. 9 uzman tarafından değerlendirilen kriterlerle ilgili en son olarak hepsinin ortalaması alınarak işlem yapılmıştır.

\section{Uygulama Verileri}

Tablo 3: "http://ebook-reader-review.toptenreviews.com" internet sitesinden alinan uygulama verileri

\begin{tabular}{|c|c|c|c|c|c|c|c|c|c|c|}
\hline & 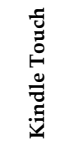 & 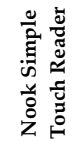 & 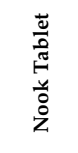 & 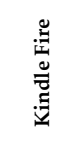 & 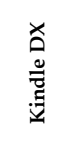 & 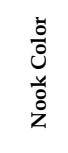 & 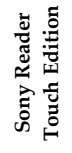 & 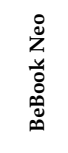 & 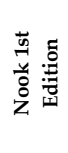 & 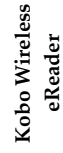 \\
\hline \multicolumn{11}{|l|}{ Design } \\
\hline Touch Screen & + & + & + & + & & + & + & + & + & \\
\hline $\begin{array}{l}\text { Screen Size } \\
\text { (diagonal } \\
\text { inches) }\end{array}$ & 6 & 6 & 7 & 7 & 9.7 & 7 & 6 & 6 & 6 & 6 \\
\hline Screen Type & E-Ink & E-Ink & LCD & LCD & E-Ink & LCD & E-ink & E-Ink & E-Ink & E-Ink \\
\hline Resolution & $\begin{array}{c}600 x \\
800 \\
\end{array}$ & $\begin{array}{c}600 x \\
800 \\
\end{array}$ & $\begin{array}{c}1024 x \\
600 \\
\end{array}$ & $\begin{array}{c}1024 x \\
600 \\
\end{array}$ & $\begin{array}{c}824 x \\
1200 \\
\end{array}$ & $\begin{array}{r}600 \times \\
1024 \\
\end{array}$ & $\begin{array}{c}800 x \\
600 \\
\end{array}$ & $\begin{array}{c}600 x \\
800 \\
\end{array}$ & $\begin{array}{c}600 x \\
800 \\
\end{array}$ & $\begin{array}{c}600 x \\
800 \\
\end{array}$ \\
\hline Overall Size & $\begin{array}{l}6.8 \mathrm{x} \\
4.7 \mathrm{x} \\
\end{array}$ & $\begin{array}{r}6.5 \times 5 \\
\times 0.47 \\
\end{array}$ & $\begin{array}{l}8.1 \mathrm{x} \\
5.0 \mathrm{x} \\
\end{array}$ & $\begin{array}{l}7.5 \mathrm{x} \\
4.7 \mathrm{x} \\
\end{array}$ & $\begin{array}{c}10.4 x \\
7.2 x \\
\end{array}$ & $\begin{array}{l}8.1 \mathrm{x} \\
5.0 \mathrm{x} \\
\end{array}$ & $\begin{array}{r}6.61 \mathrm{x} \\
4.68 \mathrm{x} \\
\end{array}$ & $\begin{array}{l}7.7 \mathrm{x} \\
4.8 \mathrm{x} \\
\end{array}$ & $\begin{array}{l}7.7 x \\
4.9 x \\
\end{array}$ & $\begin{array}{l}4.5 \mathrm{x} \\
6.5 \mathrm{x} \\
\end{array}$ \\
\hline
\end{tabular}




\begin{tabular}{|c|c|c|c|c|c|c|c|c|c|c|}
\hline (Inches) & 0.40 & & 0.48 & 0.45 & 0.4 & 0.48 & 0.38 & 0.4 & 0.5 & 0.4 \\
\hline Weight (ounces) & 7.8 & 7.48 & 14.1 & 14.6 & 18.9 & 15.8 & 7.58 & 10.5 & 12.1 & 7.8 \\
\hline \multicolumn{11}{|l|}{ Memory/Battery Life } \\
\hline Internal Memory & $4 \mathrm{~GB}$ & $2 \mathrm{~GB}$ & $16 \mathrm{~GB}$ & $8 \mathrm{~GB}$ & $4 \mathrm{~GB}$ & $8 \mathrm{~GB}$ & $2 \mathrm{~GB}$ & $\begin{array}{c}512 \mathrm{M} \\
\mathrm{B}\end{array}$ & $2 \mathrm{~GB}$ & $1 \mathrm{~GB}$ \\
\hline $\begin{array}{l}\text { Battery Life } \\
\text { (Hours) }\end{array}$ & 30 & 75 & 11.5 & 8 & 107 & 8 & 107 & 97 & 5 & $\begin{array}{c}\text { Up to } \\
10\end{array}$ \\
\hline $\begin{array}{l}\text { Removable } \\
\text { Memory }\end{array}$ & & & $\begin{array}{l}\text { Up to } \\
32 \mathrm{~GB}\end{array}$ & $32 \mathrm{~GB}$ & $6 \mathrm{~GB}$ & & & $\begin{array}{c}\text { Up } \\
\text { to } 32 \\
\text { GB }\end{array}$ & $\begin{array}{c}\text { Up } \\
\text { to } 32 \\
\text { GB }\end{array}$ & $16 \mathrm{~GB}$ \\
\hline \multicolumn{11}{|l|}{ Content } \\
\hline $\begin{array}{l}\text { eBooks in } \\
\text { Bookstore }\end{array}$ & $\begin{array}{c}1.6 \\
\text { million }\end{array}$ & $\begin{array}{c}2.5 \\
\text { million }\end{array}$ & $\begin{array}{c}2.5 \\
\text { million }\end{array}$ & $\begin{array}{c}1.6 \\
\text { million }\end{array}$ & $\begin{array}{c}1.6 \\
\text { million }\end{array}$ & $\begin{array}{c}2.5 \\
\text { million }\end{array}$ & $\begin{array}{c}2 \\
\text { milion }\end{array}$ & & & $\begin{array}{c}2.5 \\
\text { million }\end{array}$ \\
\hline $\begin{array}{l}\text { Magazines in } \\
\text { Bookstore }\end{array}$ & 272 & 160 & 230 & 272 & 272 & 160 & 20 & & & 160 \\
\hline $\begin{array}{l}\text { Newspapers in } \\
\text { Bookstore }\end{array}$ & 9 & 36 & 36 & 9 & 9 & 36 & 21 & & & 36 \\
\hline \multicolumn{11}{|l|}{ Document Formats } \\
\hline Kindle (AZW) & + & & & + & + & & & & & \\
\hline PDF & + & + & + & + & + & + & + & + & + & + \\
\hline TXT & + & & + & + & + & + & + & + & & \\
\hline MOBI & + & & & + & + & & & + & & \\
\hline PRC & + & & & + & + & & & & & \\
\hline DOC & + & & + & + & & + & & & & \\
\hline HTML & + & & & & & & & + & & \\
\hline EPUB & & + & + & & & + & + & + & + & + \\
\hline BBeB Book & & & & & & & + & & & \\
\hline PPT & & & + & & & + & & & & \\
\hline \multicolumn{11}{|l|}{ Additional Features } \\
\hline Recharge Time & 4 & 3 Hrs. & $3 \mathrm{Hrs}$ & $4 \mathrm{Hrs}$ & $\begin{array}{c}4 \\
\text { Hrs. }\end{array}$ & 3 Hrs. & $\begin{array}{c}3 \\
\text { Hrs. }\end{array}$ & $\begin{array}{c}3 \\
\text { Hrs. }\end{array}$ & $\begin{array}{c}3.5 \\
\text { Hrs. }\end{array}$ & $5 \mathrm{Hrs}$ \\
\hline Audio Formats & $\begin{array}{c}\text { MP3, } \\
\text { Audibl } \\
\text { e, AA, } \\
\text { AAX }\end{array}$ & & & $\begin{array}{c}\text { MP4, } \\
3 G P, \\
\text { WEB } \\
\text { M }\end{array}$ & $\begin{array}{c}\text { MP3, } \\
\text { MIDI, } \\
\text { WAV } \\
\text { ' } \\
\text { OGG, } \\
\text { MP4, } \\
\text { VP8 }\end{array}$ & $\begin{array}{c}\text { MP3, } \\
\text { Audib } \\
\text { le, } \\
\text { AAX }\end{array}$ & $\begin{array}{l}\text { MP3, } \\
\text { AAC }\end{array}$ & $\begin{array}{l}\text { MP3, } \\
\text { AAC }\end{array}$ & MP3 & MP3 \\
\hline Image Formats & $\begin{array}{c}\text { BMP } \\
\text { GIF } \\
\text { JPEG } \\
\text { PNG }\end{array}$ & $\begin{array}{c}\text { BMP } \\
\text { GIF } \\
\text { JPG } \\
\text { PNG }\end{array}$ & $\begin{array}{c}\text { BMP } \\
\text { GIF } \\
\text { PNG } \\
\text { JPEG }\end{array}$ & $\begin{array}{l}\text { BMP } \\
\text { GIF } \\
\text { JPG } \\
\text { PNG }\end{array}$ & $\begin{array}{c}\text { BMP } \\
\text { GIF } \\
\text { JPEG } \\
\text { PNG }\end{array}$ & $\begin{array}{c}\text { BMP } \\
\text { GIF } \\
\text { JPG } \\
\text { PNG }\end{array}$ & $\begin{array}{c}\text { BMP } \\
\text { GIF } \\
\text { JPEG } \\
\text { PNG }\end{array}$ & $\begin{array}{c}\text { GIF } \\
\text { BMP } \\
\text { JPEG } \\
\text { PNG } \\
\text { TIFF }\end{array}$ & $\begin{array}{c}\text { BMP } \\
\text { GIF } \\
\text { JPEG } \\
\text { PNG }\end{array}$ & \\
\hline \multicolumn{11}{|l|}{ Internet Capabilities } \\
\hline Wireless & Wi-Fi & Wi-Fi & Wi-Fi & Wi-Fi & $\begin{array}{c}3 \mathrm{G}, \\
\text { Whis } \\
\text { perne } \\
t\end{array}$ & Wi-Fi & Wi-Fi & Wi-Fi & $\begin{array}{c}3 \mathrm{G} \\
\mathrm{Wi}- \\
\mathrm{Fi}\end{array}$ & Wi-Fi \\
\hline
\end{tabular}

Tablo 4: İngilizce Olarak Verilmiş Olan Verilerin Türkçe Karşılıkları

\begin{tabular}{|c|c|c|c|c|c|c|c|c|c|c|}
\hline & 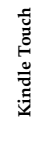 & 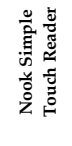 & 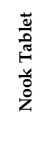 & 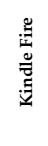 & 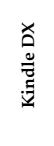 & $\begin{array}{l}\frac{\mathrm{o}}{0} \\
\text { to } \\
\frac{\mathrm{o}}{\mathrm{z}}\end{array}$ & 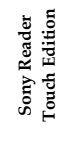 & 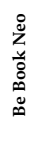 & 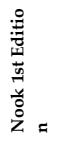 & 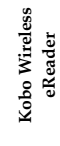 \\
\hline \multicolumn{11}{|l|}{ Tasarım } \\
\hline $\begin{array}{l}\text { Dokunmati } \\
\text { k Ekran }\end{array}$ & + & + & + & + & & + & + & + & + & \\
\hline $\begin{array}{l}\text { Ekran } \\
\text { Boyutu }\end{array}$ & 6 & 6 & 7 & 7 & 9.7 & 7 & 6 & 6 & 6 & 6 \\
\hline
\end{tabular}




\begin{tabular}{|c|c|c|c|c|c|c|c|c|c|c|}
\hline Ekran cinsi & E-Ink & E-Ink & LCD & LCD & E-Ink & LCD & E-ink & $\begin{array}{c}\text { E- } \\
\text { Ink }\end{array}$ & E-Ink & E-Ink \\
\hline Çözünürlük & $\begin{array}{c}600 \\
x \\
800 \\
\end{array}$ & $\begin{array}{c}600 \\
x \\
800 \\
\end{array}$ & $\begin{array}{c}1024 \\
x \\
600 \\
\end{array}$ & $\begin{array}{c}1024 \\
x \\
600 \\
\end{array}$ & $\begin{array}{c}824 \\
x \\
1200 \\
\end{array}$ & $\begin{array}{c}600 \\
x \\
1024 \\
\end{array}$ & $\begin{array}{c}800 \\
x \\
600 \\
\end{array}$ & $\begin{array}{c}600 \\
x \\
800 \\
\end{array}$ & $\begin{array}{c}600 \\
x \\
800 \\
\end{array}$ & $\begin{array}{c}600 \\
x \\
800 \\
\end{array}$ \\
\hline $\begin{array}{l}\text { Ekran } \\
\text { Boyutu } \\
\text { ( } 3 \text { boyutlu) }\end{array}$ & $\begin{array}{l}6.8 x \\
4.7 x \\
0.40 \\
\end{array}$ & $\begin{array}{l}6.5 \times 5 \\
\times 0.47\end{array}$ & $\begin{array}{l}8.1 \mathrm{x} \\
5.0 \mathrm{x} \\
0.48 \\
\end{array}$ & $\begin{array}{l}7.5 \mathrm{x} \\
4.7 \mathrm{x} \\
0.45 \\
\end{array}$ & $\begin{array}{c}10.4 \mathrm{x} \\
7.2 \mathrm{x} \\
0.4 \\
\end{array}$ & $\begin{array}{l}8.1 \mathrm{x} \\
5.0 \mathrm{x} \\
0.48 \\
\end{array}$ & $\begin{array}{c}6.61 x \\
4.68 x \\
0.38 \\
\end{array}$ & $\begin{array}{c}7.7 \mathrm{x} \\
4.8 \mathrm{x} \\
0.4 \\
\end{array}$ & $\begin{array}{c}7.7 x \\
4.9 x \\
0.5 \\
\end{array}$ & $\begin{array}{c}4.5 \mathrm{x} \\
6.5 \mathrm{x} \\
0.4 \\
\end{array}$ \\
\hline Ağırlık & 7.8 & 7.48 & 14.1 & 14.6 & 18.9 & 15.8 & 7.58 & 10.5 & 12.1 & 7.8 \\
\hline \multicolumn{11}{|c|}{ Hafiza ve Batarya Durumu } \\
\hline $\begin{array}{l}\text { Dahili } \\
\text { Hafıza } \\
\end{array}$ & $4 \mathrm{~GB}$ & $2 \mathrm{~GB}$ & $16 \mathrm{~GB}$ & $8 \mathrm{~GB}$ & $4 \mathrm{~GB}$ & $8 \mathrm{~GB}$ & $2 \mathrm{~GB}$ & $\begin{array}{l}512 \\
\text { MB } \\
\end{array}$ & $2 \mathrm{~GB}$ & $1 \mathrm{~GB}$ \\
\hline $\begin{array}{l}\text { Batarya } \\
\text { Ömrü(saat) }\end{array}$ & 30 & 75 & 11.5 & 8 & 107 & 8 & 107 & 97 & 5 & $\begin{array}{c}\text { Up to } \\
10\end{array}$ \\
\hline $\begin{array}{l}\text { Harici } \\
\text { Hafıza }\end{array}$ & & & $\begin{array}{l}\text { Up to } \\
32 \mathrm{~GB}\end{array}$ & $32 \mathrm{~GB}$ & $6 \mathrm{~GB}$ & & & $\begin{array}{c}\text { Up } \\
\text { to } 32 \\
\text { GB }\end{array}$ & $\begin{array}{l}\text { Up to } \\
32 \mathrm{~GB}\end{array}$ & $16 \mathrm{~GB}$ \\
\hline \multicolumn{11}{|l|}{ Kapasite } \\
\hline $\begin{array}{l}\text { Kitap } \\
\text { Kapasitesi }\end{array}$ & $\begin{array}{c}1.6 \\
\text { million }\end{array}$ & $\begin{array}{c}2.5 \\
\text { million }\end{array}$ & $\begin{array}{c}2.5 \\
\text { million }\end{array}$ & $\begin{array}{c}1.6 \\
\text { million }\end{array}$ & $\begin{array}{c}1.6 \\
\text { million }\end{array}$ & $\begin{array}{c}2.5 \\
\text { million }\end{array}$ & 2 milion & & & $\begin{array}{c}2.5 \\
\text { million }\end{array}$ \\
\hline $\begin{array}{l}\text { Dergi } \\
\text { Kapasitesi }\end{array}$ & 272 & 160 & 230 & 272 & 272 & 160 & 20 & & & 160 \\
\hline $\begin{array}{l}\text { Gazete } \\
\text { Kapasitesi }\end{array}$ & 9 & 36 & 36 & 9 & 9 & 36 & 21 & & & 36 \\
\hline \multicolumn{11}{|c|}{ Doküman Formatları } \\
\hline $\begin{array}{l}\text { Kindle } \\
\text { (AZW) }\end{array}$ & + & & & + & + & & & & & \\
\hline PDF & + & + & + & + & + & + & + & + & + & + \\
\hline TXT & + & & + & + & + & + & + & + & & \\
\hline MOBI & + & & & + & + & & & + & & \\
\hline PRC & + & & & + & + & & & & & \\
\hline DOC & + & & + & + & & + & & & & \\
\hline HTML & + & & & & & & & + & & \\
\hline EPUB & & + & + & & & + & + & + & + & + \\
\hline BBeB Book & & & & & & & + & & & \\
\hline PPT & & & + & & & + & & & & \\
\hline \multicolumn{11}{|c|}{ Ekstra Özellikler } \\
\hline $\begin{array}{l}\text { Batarya Şarj } \\
\text { Süresi }\end{array}$ & 4 & 3 Hrs. & $3 \mathrm{Hrs}$ & $4 \mathrm{Hrs}$ & 4 Hrs. & 3 Hrs. & 3 Hrs. & $\begin{array}{c}3 \\
\text { Hrs. }\end{array}$ & $\begin{array}{c}3.5 \\
\text { Hrs. }\end{array}$ & $5 \mathrm{Hrs}$ \\
\hline $\begin{array}{l}\text { Ses } \\
\text { Formatları }\end{array}$ & $\begin{array}{c}\text { MP3 } \\
\text { Audi } \\
\text { ble } \\
\text { AA } \\
\text { AAX }\end{array}$ & & & $\begin{array}{c}\text { MP4 } \\
\text { 3GP } \\
\text { WEB } \\
\text { M }\end{array}$ & $\begin{array}{c}\text { MP3, } \\
\text { MIDI, } \\
\text { WAV, } \\
\text { OGG, } \\
\text { MP4, } \\
\text { VP8 }\end{array}$ & $\begin{array}{c}\text { MP3, } \\
\text { Audi } \\
\text { ble } \\
\text { AAX }\end{array}$ & $\begin{array}{l}\text { MP3 } \\
\text { AAC }\end{array}$ & $\begin{array}{l}\text { MP3 } \\
\text { AAC }\end{array}$ & MP3 & MP3 \\
\hline $\begin{array}{l}\text { Görüntü } \\
\text { Formatları }\end{array}$ & $\begin{array}{l}\text { BMP } \\
\text { GIF } \\
\text { JPEG } \\
\text { PNG }\end{array}$ & $\begin{array}{l}\text { BMP } \\
\text { GIF } \\
\text { JPG } \\
\text { PNG }\end{array}$ & $\begin{array}{c}\text { BMP } \\
\text { GIF } \\
\text { PNG } \\
\text { JPEG }\end{array}$ & $\begin{array}{c}\text { BMP } \\
\text { GIF } \\
\text { JPG } \\
\text { PNG }\end{array}$ & $\begin{array}{l}\text { BMP } \\
\text { GIF } \\
\text { JPEG } \\
\text { PNG }\end{array}$ & $\begin{array}{l}\text { BMP } \\
\text { GIF } \\
\text { JPG } \\
\text { PNG }\end{array}$ & $\begin{array}{c}\text { BMP } \\
\text { GIF } \\
\text { JPEG } \\
\text { PNG }\end{array}$ & $\begin{array}{c}\text { GIF } \\
\text { BMP } \\
\text { JPEG } \\
\text { PNG } \\
\text { TIFF } \\
\end{array}$ & $\begin{array}{l}\text { BMP } \\
\text { GIF } \\
\text { JPEG } \\
\text { PNG }\end{array}$ & \\
\hline \multicolumn{11}{|c|}{ Internet Durumu } \\
\hline Kablosuz & $\mathrm{Wi}-\mathrm{Fi}$ & $\mathrm{Wi}-\mathrm{Fi}$ & $\mathrm{Wi}-\mathrm{Fi}$ & $\mathrm{Wi}-\mathrm{Fi}$ & $\begin{array}{c}3 \mathrm{G}, \\
\text { Whis } \\
\text { perne } \\
t\end{array}$ & $\mathrm{Wi}-\mathrm{Fi}$ & Wi-Fi & $\begin{array}{l}\text { Wi- } \\
\text { Fi }\end{array}$ & $\begin{array}{l}\text { 3G, } \\
\text { Wi-Fi }\end{array}$ & Wi-Fi \\
\hline
\end{tabular}


Tablo 5: E-kitap okuyucu Alternatifleri için Kriterlere Göre Gruplanmış Veriler

\begin{tabular}{|c|c|c|c|c|c|c|c|c|c|c|c|}
\hline & & 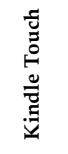 & 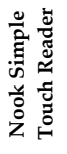 & 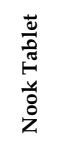 & 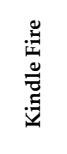 & 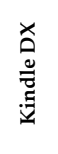 & $\begin{array}{l}\stackrel{0}{0} \\
\dot{0} \\
\ddot{o} \\
\dot{0}\end{array}$ & 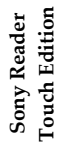 & 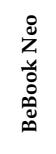 & 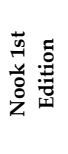 & 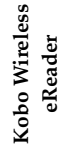 \\
\hline K1 & $\begin{array}{l}\text { Yedek parça, bakım } \\
\text { ve arıza durumu }\end{array}$ & 3 & 5 & 2 & 4 & 5 & 6 & 3 & 4 & 5 & 3 \\
\hline K2 & $\begin{array}{l}\text { Yazılım, donanım } \\
\text { ve karşılaşılan } \\
\text { teknik sorunların } \\
\text { çözümü }\end{array}$ & 4 & 6 & 3 & 2 & 4 & 3 & 5 & 6 & 5 & 4 \\
\hline K3 & Batarya Ömrü(saat) & 30 & 75 & 11.5 & 8 & 107 & 8 & 107 & 97 & 5 & 10,0 \\
\hline K4 & $\begin{array}{l}\text { Batarya Şarj Süresi } \\
\text { (saat) }\end{array}$ & 4 & 3 & 3 & 4 & 4 & 3 & 3 & 3 & 3.5 & 5 \\
\hline K5 & İnternet Durumu & 1 & 1 & 1 & 1 & 2 & 1 & 1 & 1 & 2 & 1 \\
\hline K6 & Estetik Görünüm & 5 & 7 & 3 & 4 & 6 & 5 & 7 & 6 & 7 & 5 \\
\hline K7 & Ekran cinsi & 2 & 2 & 1 & 1 & 2 & 1 & 2 & 2 & 2 & 2 \\
\hline K8 & Ekran Çözünürlük & 48 & 48 & 60 & 60 & 96 & 60 & 48 & 48 & 48 & 48 \\
\hline K9 & $\begin{array}{l}\text { Doküman } \\
\text { Formatları }\end{array}$ & 7 & 2 & 5 & 6 & 5 & 5 & 4 & 5 & 2 & 2 \\
\hline K10 & Ses Formatları & 4 & 0 & 0 & 4 & 6 & 3 & 2 & 2 & 1 & 1 \\
\hline K11 & Görüntü Formatları & 4 & 4 & 4 & 4 & 4 & 4 & 4 & 4 & 4 & 0 \\
\hline K12 & Keyboard & 2 & 2 & 2 & 2 & 1 & 2 & 2 & 2 & 2 & 1 \\
\hline K13 & Ekran Boyutu & 6 & 6 & 7 & 7 & 9.7 & 7 & 6 & 6 & 6 & 6 \\
\hline K14 & Harici Hafiza(GB) & 0 & 0 & 32 & 32 & 6 & 0 & 0 & 32 & 32 & 16 \\
\hline K15 & Dahili Hafıza(GB) & 4 & 2 & 16 & 8 & 4 & 8 & 2 & 0,5 & 2 & 1 \\
\hline K16 & Ağırlık & 7.8 & 7.48 & 14.1 & 14.6 & 18.9 & 15.8 & 7.58 & 10.5 & 12.1 & 7.8 \\
\hline K17 & Fiyat(TL) & 309.9 & 249 & 270 & 444.9 & 875 & 319 & 765 & 600 & 149 & 365 \\
\hline
\end{tabular}

\section{Uygulama Yöntemi}

\section{AHP Yönteminin Uygulaması ve Ağırlıkların Tespiti}

Makalede, kriterlerin belirlenmesinden, sonra bu kriterlere ilişkin önem derecelerini belirleyebilmek için, üç karar verici grubundan ikili karşılaştırmalara dayanan anketleri cevaplandırmaları istenmiştir. Ağırlıkların hesaplanması için ikili karşılaştırma yöntemi kullanılmıştır. İkili karşılaştırma yönteminde değerlendirme ölçütü olarak Tablo 1’de geçen İkili Karşılaştırma Ölçeği kullanılmıştır. 
Tablo 6: Kriterlerin Karşılaştırılması

\begin{tabular}{|c|c|c|c|c|c|c|c|c|c|c|c|c|c|c|c|c|c|}
\hline & $\mathrm{K}_{1}$ & $\mathrm{~K}_{2}$ & $\mathrm{~K}_{3}$ & $\mathrm{~K}_{4}$ & $\mathrm{~K}_{5}$ & $\mathrm{~K}_{6}$ & $\mathrm{~K}_{7}$ & $\mathrm{~K}_{8}$ & $\mathrm{~K}_{9}$ & $\mathrm{~K}_{10}$ & $\mathrm{~K}_{11}$ & $\mathrm{~K}_{12}$ & $\mathrm{~K}_{13}$ & $\mathrm{~K}_{14}$ & $\mathrm{~K}_{15}$ & $\mathrm{~K}_{16}$ & $\mathrm{~K}_{17}$ \\
\hline $\mathrm{K}_{1}$ & 1 & 5 & 7 & 6 & 8 & 5 & 7 & 6 & 5 & 6 & 5 & 6 & 8 & 7 & 5 & 7 & 5 \\
\hline $\mathrm{K}_{2}$ & 0,2 & 1 & 5 & 7 & 8 & 7 & 6 & 6 & 5 & 7 & 8 & 7 & 6 & 6 & 5 & 5 & 5 \\
\hline $\mathrm{K}_{3}$ & 0,14 & 0,2 & 1 & 5 & 6 & 5 & 6 & 5 & 0,2 & 6 & 6 & 1 & 1 & 1 & 1 & 0,25 & 0,25 \\
\hline $\mathrm{K}_{4}$ & 0,17 & 0,14 & 0,2 & 1 & 0,25 & 0,17 & 1 & 1 & 0,17 & 1 & 5 & 0,5 & 1 & 1 & 1 & 0,2 & 0,2 \\
\hline $\mathrm{K}_{5}$ & 0,13 & 0,13 & 0,17 & 4 & 1 & 5 & 5 & 5 & 0,17 & 1 & 6 & 0,5 & 0,2 & 0,25 & 0,2 & 0,17 & 0,2 \\
\hline $\mathrm{K}_{6}$ & 0,2 & 0,14 & 0,2 & 6 & 0,2 & 1 & 3 & 3 & 0,17 & 0,2 & 5 & 0,5 & 0,33 & 0,33 & 0,33 & 0,17 & 0,2 \\
\hline $\mathrm{K}_{7}$ & 0,14 & 0,17 & 0,17 & 1 & 0,2 & 0,33 & 1 & 4 & 0,17 & 1 & 6 & 1 & 1 & 1 & 1 & 0,17 & 0,2 \\
\hline $\mathrm{K}_{8}$ & 0,17 & 0,17 & 0,2 & 1 & 0,2 & 0,33 & 0,25 & 1 & 0,2 & 1 & 7 & 3 & 4 & 3 & 4 & 0,14 & 0,25 \\
\hline $\mathrm{K}_{9}$ & 0,2 & 0,2 & 5 & 6 & 6 & 6 & 6 & 5 & 1 & 3 & 4 & 4 & 3 & 6 & 6 & 0,2 & 0,25 \\
\hline $\mathrm{K}_{10}$ & 0,17 & 0,14 & 0,17 & 1 & 1 & 5 & 1 & 1 & 0,33 & 1 & 7 & 0,2 & 0,33 & 0,17 & 0,17 & 0,2 & 0,25 \\
\hline $\mathrm{K}_{11}$ & 0,2 & 0,13 & 0,17 & 0,2 & 0,17 & 0,2 & 0,17 & 0,14 & 0,25 & 0,14 & 1 & 0,17 & 0,17 & 0,17 & 0,17 & 0,25 & 0,25 \\
\hline $\mathrm{K}_{12}$ & 0,17 & 0,14 & 1 & 2 & 2 & 2 & 1 & 0,33 & 0,25 & 5 & 6 & 1 & 0,25 & 0,5 & 0,13 & 0,25 & 0,25 \\
\hline $\mathrm{K}_{13}$ & 0,13 & 0,17 & 1 & 1 & 5 & 3 & 1 & 0,25 & 0,33 & 3 & 6 & 4 & 1 & 0,25 & 0,14 & 0,2 & 0,2 \\
\hline $\mathrm{K}_{14}$ & 0,14 & 0,17 & 1 & 1 & 4 & 3 & 1 & 0,33 & 0,17 & 6 & 6 & 2 & 4 & 1 & 6 & 0,2 & 0,2 \\
\hline $\mathrm{K}_{15}$ & 0,2 & 0,2 & 1 & 1 & 5 & 3 & 1 & 0,25 & 0,17 & 6 & 6 & 8 & 7 & 0,17 & 1 & 0,2 & 0,2 \\
\hline $\mathrm{K}_{16}$ & 0,14 & 0,2 & 4 & 5 & 6 & 6 & 6 & 7 & 5 & 5 & 4 & 4 & 5 & 5 & 5 & 1 & 5 \\
\hline $\mathrm{K}_{17}$ & 0,2 & 0,2 & 4 & 5 & 5 & 5 & 5 & 4 & 4 & 4 & 4 & 4 & 5 & 5 & 5 & 0,2 & 1 \\
\hline Toplam & 3,7 & 8,5 & 31,28 & 53,2 & 58,02 & 57,03 & 51,42 & 49,3 & 22,58 & 56,34 & 92 & 46,87 & 47,28 & 37,84 & 41,14 & 15,8 & 18,9 \\
\hline
\end{tabular}

Belirlenen ölçütlerin ikili karşılaştırma matrisleri Tablo 6'da gösterilmektedir. İkili karşılaştırma matrisinin oluşturulmasından sonra bu matrisin ilk olarak normalize edilip daha sonra her kriterin ağırlıkların bulunması gerekir. Normalize edilmiş ve her kriter için ağırlıkların hesaplanmış olan değerler Tablo 7'de hesaplanmış olan verilen ağırlıkların tutarlılığı sınanması gerekir. Tutarlılık oranının 0,10'nun altında kalması durumunda oluşturulan ikili karşılaştırma matrisinin tutarlılığından bahsedilebilir. 
Tablo 7: Kriterlerin A $\breve{g} ı$ rlıkları

\begin{tabular}{|c|c|c|c|c|c|c|c|c|c|c|c|c|c|c|c|c|c|c|}
\hline & $\mathrm{K}_{1}$ & $\mathrm{~K}_{2}$ & K3 & K4 & K5 & $\mathrm{K}_{6}$ & K7 & K8 & K9 & K10 & $\mathrm{K}_{11}$ & $\mathrm{~K}_{12}$ & $K_{13}$ & K14 & K15 & K16 & K17 & Iriter \\
\hline & 71 & 9 & & 3 & 38 & 8 & 36 & 22 & 22 & 0,106 & 0,054 & 0,128 & 169 & 185 & 122 & 443 & 1265 & 198512 \\
\hline K & 154 & 0,118 & 16 & 0,132 & 0,138 & 0,123 & 0,117 & 0,122 & 222 & 0,124 & 0,087 & 0,149 & 0,127 & 159 & $2 \angle 4$ & 111 & 265 & 14899 \\
\hline ns & & 0,024 & 0,032 & $0, \mathrm{C}$ & 0, & 0,088 & 0,117 & 0,101 & 0,009 & 0,106 & 0,065 & 0 & 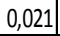 & 0 & 4 & 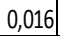 & D13 & 5295 \\
\hline $\mathrm{K}_{4}$ & 045 & 0,017 & 0,006 & 0,019 & 0,004 & 0,003 & 019 & 0,02 & 0,007 & 0,018 & 0,054 & 0,011 & 0,021 & 0,02 & 0 & 0,0 & 0,01 & 01879 \\
\hline $\mathrm{K}$ & & 15 & & & 7 & 0,088 & y) &, 101 & $0 / 7$ & 0,018 & 0,065 & 0 & 0,004 & 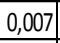 & 0,005 & & 0,01 & 13356 \\
\hline $\mathrm{K}_{6}$ & 054 & 0,017 & 0,006 & 0,113 & 0,003 & 0,018 & 0,058 & 0,061 & 0,007 & 0,004 & 0,054 & 0,011 & 0,007 & 0,009 & 8 & 0,0 & 0,011 & 226555 \\
\hline $\mathrm{K}_{7}$ & 0,039 & 0,02 & 0,005 & 0,019 & 0,003 & 0,006 & 0,019 & 0,081 & 0,007 & 0,018 & 0,065 & 0,021 & 0,021 & 0,026 & 0,024 & 0,0 & 0,011 & 0,023357 \\
\hline 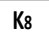 & \begin{tabular}{|l|}
0,045 \\
\end{tabular} & 0,02 & 0,006 & 0,019 & 0,003 & 0,006 & 0,005 & 0,02 & 0,009 & 0,018 & 0,076 & 0,064 & 0,085 & $0, \mathrm{C}$ & 0, & 0 & 0 & 03379 \\
\hline Kg & 0,054 & 0,024 & 16 & 0,113 & 0,103 & 0,105 & 0,117 & 0,101 & 0,044 & 0,053 & 0,043 & 0,08 & 0,06 & 0,1 & 0,1 & 0,0 & 0,0 & 08219 \\
\hline$\kappa_{110}$ & 0,045 & 0,017 & 0,005 & 0,019 & 0,017 & 0,088 & 0,019 & 0,02 & 0,015 & 0,018 & 0,076 & 0,00 & 0,007 & 0,0 & 0,0 & 0,0 & 0,013 &, 02265 \\
\hline$K_{11}$ & 0,054 & 0,015 & 0,005 & 0,004 & 0,003 & 0,004 & 0,003 & 0,003 & 0,011 & 0,003 & 0,011 & 0,004 & 0,004 & 0,004 & 0,004 & 0 & 0,013 & 0,00939 \\
\hline$K_{12}$ & 0,045 & 0,017 & 0,032 & 0,038 & 0,034 & 0,035 & 0,019 & 0,007 & 0,011 & 0,089 & 0,065 & 0,021 & 0,00 & 0,0 & 0,0 & 0,0 & 0,0 & 227313 \\
\hline$K_{13}$ & \begin{tabular}{|l|}
0,034 \\
\end{tabular} & 0,02 & 0,032 & 0,019 & 0,086 & 0,053 & 0,019 & 0,005 & 0,015 & 0,053 & 0,065 & 0,085 & 0,021 & 0,007 & 0,003 & 0,013 & 0,0 & 03180 \\
\hline $\mathrm{K}_{14}$ & 0,039 & 0,02 & 0,032 & 0,019 & 0,069 & 0,053 & 0,019 & 0,007 & 0,007 & 0,106 & 0,065 & 0,043 & 0,085 & 0,02 & 0,146 & 0,013 & 0,011 & 0,044637 \\
\hline$K_{15}$ & 0,054 & 0,024 & 0,032 & 0,019 & 0,086 & 0,053 & 0,019 & 0,005 & 0,007 & 0,106 & 0,065 & 0,171 & 0,148 & 0,004 & 0,024 & 0,013 & 0,011 & 0,04951 \\
\hline $\mathrm{K}_{16}$ & 0,039 & 0,024 & 0,128 & 0,094 & 0,103 & 0,105 & 0,117 & 0,142 & 0,222 & 0,089 & 0,043 & 0,085 & 0,106 & 0,132 & 0,122 & 0,063 & 0,265 & 0,110467 \\
\hline$K_{17}$ & 0,054 & 0,024 & 0,128 & 0,094 & 0,086 & 0,088 & 0,097 & 0,081 & 0,177 & 0,071 & 0,043 & 0,085 & 0,106 & 0,132 & 0,122 & 0,013 & 0,053 & 0,08553 \\
\hline
\end{tabular}

Tutarlılık oranı 0,035 olarak bulunmuştur. Oluşturduğumuz ikili karşılaştırma matrisindeki ağırlıklandırmalarımız tutarlıdır.

\section{TOPSIS Yönteminin Uygulanması}

\section{Adım 1: Amaçların belirlenmesi ve değerlendirme kriterlerinin} tanımlanmasi.

Yapılan literatür çalışması ve uzman görüşleri çerçevesinde 17 kriter belirlenmiş ve bütün karşılaştırmalar bu kriterlere göre yapılmıştır.

\section{Adım 2: Karar Matrisinin (A) Oluşturulması.}

İkinci adımda, alternatifler, kriterler, kriter ağırlıkları ve alternatiflerin ilgili kriterlere göre aldığı değerler bir veri matrisinde tablo haline getirilmiştir ve aşağıda sunulmuştur. " $\mathrm{F}$ " faydayı ve " $\mathrm{M}$ " maliyeti temsil etmektedir. 
Tablo 8: Karar Matrisi

\begin{tabular}{|c|c|c|c|c|c|c|c|c|c|c|c|c|c|c|c|c|c|c|}
\hline & & 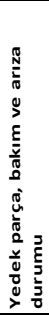 & 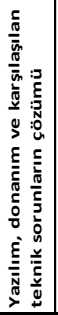 & 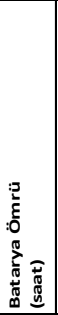 & 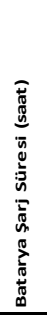 & 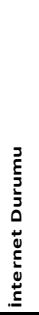 & 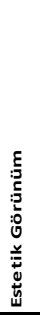 & $\begin{array}{l}\overline{5} \\
\frac{\bar{n}}{0} \\
\frac{5}{0} \\
\frac{5}{4}\end{array}$ & 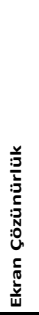 & 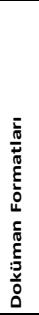 & 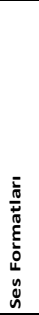 & 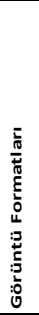 & 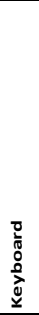 & 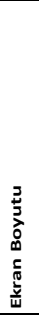 & 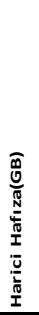 & 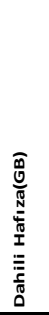 & 兰 & $\underset{\vec{E}}{\vec{E}}$ \\
\hline & & $\mathrm{K}_{1}$ & $\mathrm{~K}_{2}$ & $\mathrm{~K}_{3}$ & $\mathrm{~K}_{4}$ & $\mathrm{~K}_{5}$ & $\mathrm{~K}_{6}$ & $\mathrm{~K}_{7}$ & $\mathrm{~K}_{8}$ & Kg & $K_{10}$ & $\mathrm{~K}_{11}$ & $\mathrm{~K}_{12}$ & $\mathrm{~K}_{13}$ & $\mathrm{~K}_{14}$ & $K_{15}$ & $\mathrm{~K}_{16}$ & $\mathrm{~K}_{17}$ \\
\hline Kindle Touch & $A_{1}$ & 3 & 4 & 30 & 4 & 1 & 5 & 2 & 48 & 7 & 4 & 4 & 2 & 6 & 0 & 4 & 7,8 & 309,9 \\
\hline $\begin{array}{l}\text { Nook Simple } \\
\text { Touch Reader }\end{array}$ & $A_{2}$ & 5 & 6 & 75 & 3 & 1 & 7 & 2 & 48 & 2 & 0 & 4 & 2 & 6 & 0 & 2 & 7,48 & 249 \\
\hline Nook Tablet & $\mathrm{A}_{3}$ & 2 & 3 & 115 & 3 & 1 & 3 & 1 & 60 & 5 & 0 & 4 & 2 & 7 & 32 & 16 & 14,1 & 270 \\
\hline Kindle Fire & $\mathrm{A}_{4}$ & 4 & 2 & 8 & 4 & 1 & 4 & 1 & 60 & 6 & 4 & 4 & 2 & 7 & 32 & 8 & 14,6 & 444,9 \\
\hline Kindle DX & $\mathrm{A}_{5}$ & 5 & 4 & 107 & 4 & 2 & 6 & 2 & 96 & 5 & 6 & 4 & 1 & 9,7 & 6 & 4 & 18,9 & 875 \\
\hline Nook Color & $A_{6}$ & 6 & 3 & 8 & 3 & 1 & 5 & 1 & 60 & 5 & 3 & 4 & 2 & 7 & 0 & 8 & 15,8 & 319 \\
\hline \begin{tabular}{|l|} 
Sony Reader Touch \\
Edition
\end{tabular} & $A_{7}$ & 3 & 5 & 107 & 3 & 1 & 7 & 2 & 48 & 4 & 2 & 4 & 2 & 6 & 0 & 2 & 7,58 & 765 \\
\hline BeBook Neo & $A_{8}$ & 4 & 6 & 97 & 3 & 1 & 6 & 2 & 48 & 5 & 2 & 4 & 2 & 6 & 32 & 0,5 & 10,5 & 600 \\
\hline Nook 1st Edition & $A_{9}$ & 5 & 5 & 5 & 3,5 & 2 & 7 & 2 & 48 & 2 & 1 & 4 & 2 & 6 & 32 & 2 & 12,1 & 149 \\
\hline \begin{tabular}{|l|} 
Kobo Wireless \\
eReader \\
\end{tabular} & $A_{10}$ & 3 & 4 & 10 & 5 & 1 & 5 & 2 & 48 & 2 & 1 & 0 & 1 & 6 & 16 & 1 & 7,8 & 365 \\
\hline & & $M$ & $F$ & $F$ & $M$ & $F$ & $F$ & $F$ & $F$ & $F$ & $F$ & $F$ & $F$ & $F$ & $F$ & $F$ & $M$ & $M$ \\
\hline
\end{tabular}

\section{Adım 3: Standart Karar Matrisinin (R) Oluşturulması}

Üçüncü adımda bu karar matrisinin ölçeklendirilmesi Standart Karar Matrisinin (R) oluşturulması gerekmektedir. Oluşturulan Standart Karar Matrisi aşağıda verilmiştir.

Tablo 9: Standart Karar Matrisi

\begin{tabular}{|c|c|c|c|c|c|c|c|c|c|c|c|c|c|c|c|c|c|}
\hline & $\mathrm{K}_{1}$ & $\mathrm{~K}_{2}$ & $\mathrm{~K}_{3}$ & $\mathrm{~K}_{4}$ & $\mathrm{~K}_{5}$ & $\mathrm{~K}_{6}$ & $\mathrm{~K}_{7}$ & $\mathrm{~K}_{8}$ & $\mathrm{~K}_{9}$ & $\mathrm{~K}_{10}$ & $\mathrm{~K}_{11}$ & $\mathrm{~K}_{12}$ & $\mathrm{~K}_{13}$ & $\mathrm{~K}_{14}$ & $\mathrm{~K}_{15}$ & $\mathrm{~K}_{16}$ & $\mathrm{~K}_{17}$ \\
\hline $\mathrm{A}_{1}$ & 3 & 4 & 30 & 4 & 1 & 5 & 2 & 48 & 7 & 4 & 4 & 2 & 6 & 0 & 4 & 7,8 & 309,9 \\
\hline $\mathrm{A}_{2}$ & 5 & 6 & 75 & 3 & 1 & 7 & 2 & 48 & 2 & 0 & 4 & 2 & 6 & 0 & 2 & 7,48 & 249 \\
\hline $\mathrm{A}_{3}$ & 2 & 3 & 115 & 3 & 1 & 3 & 1 & 60 & 5 & 0 & 4 & 2 & 7 & 32 & 16 & 14,1 & 270 \\
\hline $\mathrm{A}_{4}$ & 4 & 2 & 8 & 4 & 1 & 4 & 1 & 60 & 6 & 4 & 4 & 2 & 7 & 32 & 8 & 14,6 & 444,9 \\
\hline $\mathrm{A}_{5}$ & 5 & 4 & 107 & 4 & 2 & 6 & 2 & 96 & 5 & 6 & 4 & 1 & 9,7 & 6 & 4 & 18,9 & 875 \\
\hline $\mathrm{A}_{6}$ & 6 & 3 & 8 & 3 & 1 & 5 & 1 & 60 & 5 & 3 & 4 & 2 & 7 & 0 & 8 & 15,8 & 319 \\
\hline $\mathrm{A}_{7}$ & 3 & 5 & 107 & 3 & 1 & 7 & 2 & 48 & 4 & 2 & 4 & 2 & 6 & 0 & 2 & 7,58 & 765 \\
\hline $\mathrm{A}_{8}$ & 4 & 6 & 97 & 3 & 1 & 6 & 2 & 48 & 5 & 2 & 4 & 2 & 6 & 32 & 0,5 & 10,5 & 600 \\
\hline $\mathrm{A}_{9}$ & 5 & 5 & 5 & 3,5 & 2 & 7 & 2 & 48 & 2 & 1 & 4 & 2 & 6 & 32 & 2 & 12,1 & 149 \\
\hline $\mathbf{A}_{10}$ & 3 & 4 & 10 & 5 & 1 & 5 & 2 & 48 & 2 & 1 & 0 & 1 & 6 & 16 & 1 & 7,8 & 365 \\
\hline Ağırlıklar & 0,198 & 0,149 & 0,053 & 0,019 & 0,034 & 0,027 & 0,023 & 0,034 & 0,082 & 0,023 & 0,009 & 0,027 & 0,032 & 0,045 & 0,05 & 0,11 & 0,086 \\
\hline
\end{tabular}




\section{Adım 4: A ̆̆ırlıklı Standart Karar Matrisinin (V) Oluşturulması.}

Standart karar matrisinin ardından belirlenen ölçüt ağırlıkları kullanılarak ağırlıklandırılmış standart karar matrisi oluşturulur. Ağırlıklandırılmış karar matrisi, ölçüt ağrılığının her bir matris elemanı ile çarpılmasıyla elde edilir. Ağırlıklandırılmış standart karar matrisi Tablo 10 'de gösterilmektedir.

Tablo 10: Ağırlıklı Standart Karar Matrisi

\begin{tabular}{|c|c|c|c|c|c|c|c|c|c|c|c|c|c|c|c|c|c|}
\hline & $K_{1}$ & $K_{2}$ & $K_{3}$ & $K_{4}$ & $K_{5}$ & $K_{6}$ & $K_{7}$ & $K_{8}$ & $K_{9}$ & $K_{10}$ & $K_{11}$ & $K_{12}$ & $K_{13}$ & $K_{14}$ & $K_{15}$ & $K_{16}$ & $K_{17}$ \\
\hline$A_{1}$ & 0,594 & 0,596 & 1,59 & 0,076 & 0,034 & 0,135 & 0,046 & 1,632 & 0,574 & 0,092 & 0,036 & 0,054 & 0,192 & 0 & 0,2 & 0,858 & 26,65 \\
\hline$A_{2}$ & 0,99 & 0,894 & 3,975 & 0,057 & 0,034 & 0,189 & 0,046 & 1,632 & 0,164 & 0 & 0,036 & 0,054 & 0,192 & 0 & 0,1 & 0,823 & 21,41 \\
\hline$A_{3}$ & 0,396 & 0,447 & 6,095 & 0,057 & 0,034 & 0,081 & 0,023 & 2,04 & 0,41 & 0 & 0,036 & 0,054 & 0,224 & 1,44 & 0,8 & 1,551 & 23,22 \\
\hline$A_{4}$ & 0,792 & 0,298 & 0,424 & 0,076 & 0,034 & 0,108 & 0,023 & 2,04 & 0,492 & 0,092 & 0,036 & 0,054 & 0,224 & 1,44 & 0,4 & 1,606 & 38,26 \\
\hline$A_{5}$ & 0,99 & 0,596 & 5,671 & 0,076 & 0,068 & 0,162 & 0,046 & 3,264 & 0,41 & 0,138 & 0,036 & 0,027 & 0,31 & 0,27 & 0,2 & 2,079 & 75,25 \\
\hline$A_{6}$ & 1,188 & 0,447 & 0,424 & 0,057 & 0,034 & 0,135 & 0,023 & 2,04 & 0,41 & 0,069 & 0,036 & 0,054 & 0,224 & 0 & 0,4 & 1,738 & 27,43 \\
\hline$A_{7}$ & 0,594 & 0,745 & 5,671 & 0,057 & 0,034 & 0,189 & 0,046 & 1,632 & 0,328 & 0,046 & 0,036 & 0,054 & 0,192 & 0 & 0,1 & 0,834 & 65,79 \\
\hline$A_{8}$ & 0,792 & 0,894 & 5,141 & 0,057 & 0,034 & 0,162 & 0,046 & 1,632 & 0,41 & 0,046 & 0,036 & 0,054 & 0,192 & 1,44 & 0,025 & 1,155 & 51,6 \\
\hline$A_{9}$ & 0,99 & 0,745 & 0,265 & 0,067 & 0,068 & 0,189 & 0,046 & 1,632 & 0,164 & 0,023 & 0,036 & 0,054 & 0,192 & 1,44 & 0,1 & 1,331 & 12,81 \\
\hline$A_{10}$ & 0,594 & 0,596 & 0,53 & 0,095 & 0,034 & 0,135 & 0,046 & 1,632 & 0,164 & 0,023 & 0 & 0,027 & 0,192 & 0,72 & 0,05 & 0,858 & 31,39 \\
\hline & $\mathrm{M}$ & $\mathrm{F}$ & $\mathrm{F}$ & $\mathrm{M}$ & $\mathrm{F}$ & $\mathrm{F}$ & $\mathrm{F}$ & $\mathrm{F}$ & $\mathrm{F}$ & $\mathrm{F}$ & $\mathrm{F}$ & $\mathrm{F}$ & $\mathrm{F}$ & $\mathrm{F}$ & $\mathrm{F}$ & $\mathrm{M}$ & $\mathrm{M}$ \\
\hline
\end{tabular}

Adım 5: Pozitif İdeal $\left(A^{*}\right)$ ve Negatif İdeal $\left(A^{-}\right)$Çözümlerin

\section{Oluşturulması.}

Ağırlıklandırılmış standart karar matrisinin oluşturulmasının ardından pozitif ideal $A^{*}$ ve negatif ideal $\left(A^{-}\right)$çözüm setleri oluşturulur. Pozitif ideal $A^{*}$ çözüm seti için elde edilen ağırlıklandırılmış karar matrisinin sütunlarında yer alan en büyük değer seçilirken, $A^{-}$çözüm seti için en küçük değerler seçilir. Buna göre elde edilen çözüm setleri şu şekildedir;

Tablo 11: Pozitif İdeal ( $A^{*}$ ) ve Negatif İdeal ( $A^{-}$) Çözümleri

\begin{tabular}{|c|c|c|c|c|c|c|c|c|c|c|c|c|c|c|c|c|c|}
\hline Wead Poilit" & 03960 & 0,099 & 60955 & 0,057 & 0,068 & 0,190 & ONG6 & 3,164 & 0,574 & $0,1,38$ & 0,360 & 0,054 & 0,j:1LA & $1, \mathbb{A}$ & 0,8 & 0,82180 & 118,014 \\
\hline Pontit & $1,1,180$ & 0,298 & $0,0(6)^{2}$ & 1076 & ONS34 & 0,081 & OONB & 1.625 & 0,164 & 0 & 0 & ONOLZ & 0,919 & 0 & $0,0,5$ & 20,09 & \\
\hline
\end{tabular}

\section{Adım 6: Ayırım Ölçülerinin Hesaplanması.}

İdeal ve negatif ideal çözüm kümelerinin belirlenmesinden sonra 5.4 ve 5.5 formülleri kullanılarak i alternatifinin ideal ve negatif ideal çözüme olan uzaklıkları hesaplanır. 
Tablo 12:Ayırım Ölçüleri

\begin{tabular}{|c|c|c|c|}
\hline $\mathrm{S} 1_{+}$ & 14,7314 & S1- & 48,6387 \\
\hline $\mathrm{S} 2+$ & 9,17805 & S2- & 53,9821 \\
\hline $\mathrm{S3}+$ & 10,5157 & S3- & 52,3922 \\
\hline S4+ & 26,1254 & S4- & 37,0279 \\
\hline S5+ & 62,4677 & S5- & 5,67652 \\
\hline S6+ & 15,8539 & S6- & 47,8217 \\
\hline S7+ & 53,0284 & S7- & 10,994 \\
\hline S8+ & 38,8439 & S8- & 24,22 \\
\hline S9+ & 6,16207 & S9- & 62,4592 \\
\hline $\mathrm{S} 10_{+}$ & 19,4965 & S10- & 43,8888 \\
\hline
\end{tabular}

\section{Adım 7: İdeal Çözüme Göreli Yakınlığın Hesaplanması.}

Pozitif ideal çözüme ve negatif ideal çözüme olan uzaklıklar hesaplandıktan sonra, alternatiflerin sıralamasını belirleyebilmek için her alternatife ilişkin yakınlık katsayıları hesaplanır. Açıkır ki, $C_{i}$ 1'e yaklaştıkça Ai alternatifi $A^{*}$ 'e yaklaşır, $A^{-}$'ten uzaklaşır. Bu nedenle, yakınlık katsayısına göre alternatiflerin öncelik sıralamasına karar verilebilir ve mümkün alternatifler seti içinden en iyi olan alternatif seçilebilir. Yakınlık katsayısı 1'e ne kadar yakınsa adayın tercih edilme şansı o kadar büyüktür. Yakınlık katsayıları aşağıda hesaplanmış ve sıralaması Adım 8'de yapılmıştır.

Tablo 13: Yakınlkk Katsayıları

\begin{tabular}{|r|r|}
\hline$C_{1}$ & 0,76753 \\
\hline$C_{2}$ & 0,85469 \\
\hline$C_{3}$ & 0,83284 \\
\hline$C_{4}$ & 0,58632 \\
\hline$C_{5}$ & 0,0833 \\
\hline$C_{6}$ & 0,75102 \\
\hline$C_{7}$ & 0,17172 \\
\hline$C_{8}$ & 0,38406 \\
\hline$C_{9}$ & 0,9102 \\
\hline$C_{10}$ & 0,69241 \\
\hline
\end{tabular}

Adım 8: Alternatifler ideal çözüme göreli yakınlık $C_{i}^{*}$ değerine göre siralanmasi

$$
\mathrm{C} 9>\mathrm{C} 2>\mathrm{C} 3>\mathrm{C} 1>\mathrm{C} 6>\mathrm{C} 10>\mathrm{C} 4>\mathrm{C} 8>\mathrm{C} 7>\mathrm{C} 5
$$

Belirlenen ve ağırlıklandırılan kriterler çerçevesinde en iyi e-kitap okuyucunun Nook 1st Edition olduğu ortaya konmuştur. Nook 1st Edition kitap okuyucusunun özellikleri incelendiğinde fiyat kriterine göre en ucuz, 
yedek parça, bakım ve arıza durumu kriteri ile yazılım, donanım ve teknik destek kriterlerine göre en iyi ikinci sırada, estetik kriterine göre en iyi olduğu, ancak ses ve görüntü formatları açısından ise orta sıralarda olduğu görülmektedir. İnternet bağlantısı olarak birçok e-kitap okuyucusunda bulunmayan 3G özelliği bulunmaktadır.

En son sirada yer alan e-kitap okuyucusu ise önemli bir kriter olan fiyat kriterinde en yüksek değerli olmasından dolayı son sırada yer almıştır. Yüksek fiyatlı olup buna paralel diğer teknik özelliklerini incelediğimizde özelliklerin oldukça iyi olduğunu görmekteyiz Ancak, tüketici bir ürünü seçerken faydasını maksimize yapmaya çalışacağından dolayı kendisi için en uygunu seçecektir.

\section{Sonuc}

Teknoloji seçimi günümüzde herkes açısından önem kazanan bir konudur. Yapılan uygulamada, henüz daha başlangıç aşamasında olan ve ileriki yıllarda daha da yaygınlaşacağı değerlendirilen e-kitap için en uygun kullanılabilecek e-kitap okuyucu seçilmesi için bir karar süreci oluşturulmak istenmiş ve literatür taraması sonucunda e-kitap okuyucu seçimi ile ilgili kriterler belirlenmeye çalışılmıştır. Yapılan araştırma çerçevesinde konuyla ilgili hem yerli hem de yabancı literatürde konuyla ilgili henüz bir standartlığın olmadığı ve gerekli araştırmanın yapılmadığ 1 görülmüştür. Ancak araştırma sonucunda bir e-kitap okuyucusunun sahip olması gereken önemli özellikler olarak 17 adet kriter belirlenebilmiştir. Bu kriterler sırasıyla yedek parça, bakım ve arıza durumu, yazılım, donanım ve karşılaşılan teknik sorunların çözümü, batarya ömrü, şarj edilme süresi, ağ bağlantı çeşiti (Wi-Fi veya 3G), estetik görünüm, ekran cinsi, ekran çözünürlüğü, doküman formatları, ses formatı, görüntü formatları, klavye, ekran boyutu, harici hafıza, dahili hafıza, ağırlık ve fiyat kriterleri olduğu tespit edilmiştir. $\mathrm{Bu}$ tespit edilen kriterlerin birbirine kıyasla önem derecesini ortaya koymak amacıyla uzman görüşleri alınmış ve uzmanların yaptıkları ikili karşılaştırmaları sonucunda en önemli 4 kriterin sırasıyla yedek parça, bakım ve arıza durumu kriteri, yazılım, donanım ve karşılaşılan teknik sorunların çözümü kriteri, ağırlık kriteri ve fiyat kriteri olarak ortaya konmuştur. Gerçekten de e-kitap okuyucuların seçimiyle ilgili olarak yerli ve yabancı internet sitelerinde kullanıcılar tarafından forumlarda yazılan hususlar incelendiğinde teknik özelliklerine girmeden ortaya konan bu kriterler tartışılmakta ve önerilerde bulunulmaktadır. Bu konular ortaya konduktan sonra teknik özelliklerle ilgili kısımlar hakkında fikirler paylaşıldığı görülmüştür. 


\section{Kaynakça:}

Abdullah, N. ve Gibb, F. (2008). Students' Attitudes Towards E-books in A Scottish Higher Education Institute: Part 2 Analysis of E-book Usage, Library Review, 57, 9, 676-689.

Aktaş, R. (2004). Karar Teorisi, KHO Yayınları, Ankara.

Barkan, M. (1994). Eğitim İletişiminin Kavramsal Temelleri ve İşlevleri, Anadolu Üniversitesi İletişim Bilimleri Fakültesi Yayınları, Eskişehir.

Başkaya, Z. ve Öztürk, B. (2011). Bulanık TOPSIS ile Satış Elemanı Adaylarının Değerlemesi. Business and Economics Research Journal, Volume 2, Number 2, pp. 77-100

Broadhurst, D. ve Watson, J. (2012). E-Book Readers for Full-Time MBA Students: An Investigation in Manchester, Journal of Business \& Finance Librarianship, 17:170-182

Chu, H. (2003). Electronic Books: Viewpoint From Users And Potential Users, Library Hi Tech, 21, 3, 310-346.

Consumer Reports, December 2012, Vol. 77 Issue 12, 30-31 www.consumer repors.org, erişim tarihi 12.12.2012.

Çınar, N.T. (2010). Kuruluş Yeri Seçiminde Bulanık TOPSIS Yöntemi ve Bankacllk Sektöründe Bir Uygulama. KMÜ Sosyal ve Ekonomik Araştırmalar Dergisi, 12(18): 37-45.

Duran, E. ve Ertuğrul,B. (2012). Illköğretim Simf Öğretmenlerinin Elektronik Ders Kitaplarına Yönelik Görüşleri, Türk Eğitim Bilimleri Dergisi, 10(2), 347-365

Ertuğrul, İ. ve Karakaşoğlu, N. (2010). Electre ve Bulanık AHP Yöntemleri ile Bir İşletme İçin Bilgisayar Seçimi, Dokuz Eylül Üniversitesi İktisadi ve İdari Bilimler Fakültesi Dergisi, Cilt:25, Sayı:2.

Ganapati, P. (2010). http://www.wired.com/gadgetlab/2009/05/buyingguide-e-book-reader/ Erişim Tarihi: 13.12.2012.

Göksu, A. ve Güngör, E. (2008). Bulanık Analitik Hiyerarşik Proses ve Üniversite Tercih Siralamasında Uygulanmast, Süleyman Demirel Üniversitesi İktisadi ve idari Bilimler Fakültesi Dergisi Y. C.13, S.3

Hwang, C.L., Yoon, P. (1981). Multiple Attribute Decision Making In: Lecture Notes in Economics and Mathematical Systems, Springer-VerlagBerlin,

Jung, S., M. ve Lim, K., B. (2009). Leading Future Education: Development of Digital Textbooks in KOREA, 12th UNESCO-APEID International 
Conference Quality Innovations for Teaching and Learning, Bangkok, Thailand, 24-26.

Jung, J., Chan-Olmsted, S., Park, B. ve Kim, Y. (2011). Factors affecting ebook reader awareness, interest, and intention to use, New Media \& Society, 14(2) 204-224.

Karaçolak, B. ve Ünal, M.F., (2012). Örnek Bir Kamu Kurumunda İşe Alım ve Mülakat Sürecine Yeni Bir Yaklaşım; Bulanık AHP Yöntemi İle Aday Değerlendirme Kriterlerinin Önceliklendirilmesi. http://www.pglobal.com.tr/ahpmakale.pdf (22.10.2012)

Kim, M., Yoo, K.,H, Park, C. ve Yoo, J., S. (2010). Development of a digital textbook standard format based on XML, Computer Science and Information Technology AST/UCMA/ISA/ACN 2010 Conferences, June, Miyazaki, Bildiriler Kitabı: 363-377.

Konya, Ü. (2004). Elektronik Kitaplar, Aysel Yontar'a Armağan Kitabı, TKD İstanbul Şubesi, İstanbul 2004, 67-71.

Küçük, O. ve Ecer, F. (2007). Bulanık TOPSIS Kullanılarak Tedarikçilerin Değerlendirilmesi ve Erzurum'da Bir Uygulama. Ekonomik ve Sosyal Araştırmalar Dergisi, Cilt:3, Yı1:3, Sayı:1, 3: 45-65.

Lam, P., Lam, S.L., Lam, J. ve McNaught, C. (2009). Usability And Usefulness of Ebooks On PPCS: How Students' Opinions Vary Over Time, Australasian Journal of Educational Technology, 25, 1, 30-44.

Mahmoodzadeh, S., Shahrabi, J., Pariazar, M and Zaeri M. S. (2007). Project Selection by Using Fuzzy AHP and Topsis Technique International, Journal of Human and Social Sciences 1;3 pp.135-140.

Mahajan, P. ve Chakravarty, R. (2007). E-Books As A Tool For Scholarly Communication: Emerging Trends and Technologies, 5th International CALIBER, February, Chandigarh, Bildiriler Kitabı: 554-569.

Mallet, E. (2010). A screen too far? Findings from an e-book reader pilot. Serials, 23(2), 140-144.

McFall, R. (2005). Electronic Textbooks That Transform How Textbooks Are Used, The Electronic Library, 23, 1, 72-81.

Milli Eğitim Bakanlığının 5 Haziran 2009 tarihli, 2009/21 Karar Nolu ve Hayat Boyu Öğrenme Strateji Belgesi, 2

Önder, I. (2010). Elektronik Kitap Olgusu ve Türkiye'de Durum. Yayınlanmamış Yüksek Lisans Tezi, Ankara Üniversitesi, Sosyal Bilimler Enstitüsü, Ankara. 
Özgörmüş, E., Mutlu, Ö. ve Güner, H. (2005). Bulanık AHP İle Personel Seçimi, V. Ulusal Üretim Arastırmaları Sempozyumu, İstanbul Ticaret Üniversitesi.

Özbay, M. (2007). Türkçe Özel Öğretim Yöntemleri II. Ankara: Öncü Kitap.

Rao, R.V. (2008). Evaluation of environmentally conscious manufacturing programs using multiple attribute decision-making methods, Proceedings of the Institution of Mechanical Engineers - Part B Engineering Manufacture, Vol. 222 Issue 3, pp.441-451.

Rukancı, F. ve Anameriç, H. (2003). E-kitap teknolojisi ve kullanımı. Türk Kütüphaneciliği Dergisi,17(2), 147-166.

Shyjith, K. Ilangkumaran, M and Kumanan, S. (2008). Multi-criteria decisionmaking approach to evaluate optimum maintenance strategy in textile industry, Journal of Quality in Maintenance Engineering; Vol. 14; No. 4, pp.375-386.

Soules, A. (2008). New Types of e-books, e-book issues, and implications for the future, The Acquisitions Librarian, 19, 3, 367-388.

Şahin,Y. ve Akyer, H. (2011). Ülke Kaynaklarının Verimli Kullanımı: $4 x 4$ Arama ve Kurtarma Aracı Seçiminde AHS ve TOPSIS Yöntemlerinin Uygulaması. Süleyman Demirel Üniversitesi Vizyoner Dergisi Y.2011, C.3, S.5. S.72-87

Wilson, R. ve Landoni, M. (2008). EBONI Electronic Textbook Design Guidelines, $\quad \underline{\text { http://ebooks.strath.ac.uk/eboni/guidelines/Guidelines.pdf }}$ Erişim Tarihi: 21.10.2012.

Yazıc1, B. (2011). http://www.burcinyazici.com/en-populer-e-kitap-okuyucularininkarsilastirmasi-2374.html Erişim Tarihi: 21.11.2012.

Yıldırım, G., Karaman, S., Çelik, E. ve Esgice, M. (2011). E-kitap Okuyucuların Kullanım Deneyimlerine Yönelik Alanyazın Incelemesi, 5th International Computer \& Instructional Technologies Symposium, Firat Universitesi, Elazığ- Turkey.

Yurdakul, M. and İç, Y. T. (2001). Development of a performance measurement model for manufacturing companies using the AHP and Topsis approaches. International Journal of Production Research, Vol. 43,No. 21, p.p 4609-4641.

Yurdakul, M. ve İç, Y.T. (2003). Türk Otomotiv Firmalarının Performans Ölçümü ve Analizine Yönelik TOPSIS Yöntemini Kullanan Bir Örnek Çalışma. Gazi Üniv. Müh. Mim. Fak. Der. Cilt 18, No 1, 1-18. 